\title{
The Drivers of Managerial Practices: Firm and Country Characteristics Explaining Managerial Performance
}

\author{
Roberto Iorio $^{1} \&$ Maria Luigia Segnana ${ }^{1}$ \\ ${ }^{1}$ Department of Political and Social Studies, University of Salerno, Italy \\ Correspondence: Maria Luigia Segnana, Dept. of Economics and Management, Via Inama 5, University of \\ Trento, 38100 Trento. Italy. E-mail: marialuigia.segnana@unitn.it
}

Received: August 7, 2019

Accepted: September 23, 2019

Online Published: October 28, 2019

doi:10.5539/ijbm.v14n11p221

URL: https://doi.org/10.5539/ijbm.v14n11p221

\begin{abstract}
A large body of researches in recent years resulted in the growth of knowledge about better or worse management practices. However, comparative research using firm-level data has been limited by the different styles on management and by the unavailability of homogeneous data sources, especially in former transition and Asian countries. This study fills this gap, by using the firm-level survey by EBRD and World Bank (BEEPS V-MENA ES, 2012-2014) and by looking at the determinants of a Management quality score (MQS) for more than 17.000 firms in 36 countries of Central Asia, Eastern Europe and Northern Africa. We find that both country and firm characteristics matter for managerial skills but the ladder weight differently. In fact, the country-grouping changes, accelerates or dampens the impact of firms' characteristics on management performance and identifies the channels conducive of better managerial practices. Competition, education, and technology are important channels for the high-income countries only, whereas global value chain participation and ownership are significant channels for the low-income countries only. In particular, GVC participation enhances significantly managerial practices of firms in low-income countries especially for the lower quartile firms. Hence, this study provides empirical support for interplay between country and firm characteristics in transitional and emerging markets. In addition, it provides support for an enhanced connection between business environment reforms devoted to managerial upgrading and industrial policy devoted to enhancing best-performing firms' characteristics. As such, it suggests that only their complementary and targeted use can support management and business practices upgrading.
\end{abstract}

Keywords: managerial quality, firm performance, productivity, management practices, managerial upgrading

\section{Introduction}

The origins of cross-country differences in living standards have captured the attention of economists for years, and most researchers agree that at the centre of the variation in output per worker across countries are differences in productivity. But why do countries have different levels of productivity? Economists tend to disregard management-based explanations for productivity differences but productivity differences between countries and firms remain puzzling. The puzzle persists even at industry level. For example, within the average four-digit U.S. manufacturing industries, Syverson (2011) finds that labour productivity for plants at the 90th percentile was four times as high as plants at the 10th percentile. Even after controlling for other factors, Total Factor Productivity (TFP) was almost twice as high, with differences persistent over time and robust to controls for plant-specificities. Why is such TFP heterogeneity evident in U.S. industries as well as in all other countries where data is available? One explanation is that these persistent differences between and within industry productivity is due to hard technological innovations, as embodied in patents or the adoption of advanced equipment. Another explanation is that productivity differences reflect variations in management practices. Along the ladder explanation, research suggests that differences in managerial practices, or 'managerial quality' for short, plays an important role in explaining productivity differences across countries. Studies show the strong correlation between the quality of management practices and firms performance or productivity and this applies not only to advanced countries but also to developing economies.

This interest of scholars in the link between managerial quality and performance has surely gained momentum after the seminal contributions and applications by Bloom and Van Reenen (Bloom \& Van 
Reenen, 2007; Bloom et al., 2010, 2013), with their general conclusion that there is a set of good managerial practices whose implementation is conducive to higher firm performance. Managerial practices matter not only at both country and firm level but also at plant level: they varied not just among companies, but also within them. Variations among plants belonging to the multi-plant firms due to the differences across establishments within the very same firm. The puzzle is now multifaceted.

First, the TFP spread across countries, industries, firms and plants persist cross section and over time and finds only partial explanations (Note 1). Hence, resource misallocation across firms within industries is important, yet not the main factor that can account for cross-country productivity differentials (Note 2), especially across developing economies (Note 3). Second, the empirical evaluation shows that differences in management quality could account for significant amount of total factor productivity differences between and within firms and plants (Bloom et al., 2017a). Third, managerial quality is still the missing and relatively unexplored channel. Sometimes, managers and firms seem unaware of their poor management, with significant managerial overconfidence (Note 4) affecting productivity differences at various levels.

Given this economic premise, if we do not shy away from management-based explanations of productivity differences, disentangling managerial quality sources is one step forward to tackle one missing piece of the puzzle: the source of productivity differences. More precisely, the central question of this paper is about the determinants of managerial quality across countries. The focus is on why firms in different countries have very heterogeneous managerial quality. In other words, why so many firms exist with apparently inferior management practices and why this varies so much across countries and across firms. To do so, we have been using BEEPS V-MENA ES datasets covering many economies not only European but also Asian and Northern African countries, i.e. relatively understudied regions, or regions for which a scant empirical evidence is available.

Anecdotal evidence suggests that some of these countries began their transition in the 1990s with the dissolution of the Soviet Union in 1991 and in some case they are still undergoing transition from centrally planned to market-oriented economies. While there are many well-managed firms, many other firms are operating with extremely old-fashioned management practices. The lack of appropriate managerial skills is a possible explanation for lower productivity found, for instance, among state-owned or formerly state-owned firms of transition countries (Note 5) as well as among less advanced countries, when the impacts of training programmes on improvement of business practices are searched for (McKenzie \& Woodruff, 2016). Even corruption plays a very significant role, affecting aggregate productivity and firm performance by deteriorating firm management practices (Athanasouli \& Goujard, 2015) or by 'greasing the wheels' of firm performance (Goedhuys-Degelin et al., 2016), with very different regional effects (Litvinova \& Segnana, 2018). Thus, productivity differences might reflect differences in managerial ability, organizational capital, management practices and other intangible factors along with potentially random factors about choosing the right combination of location, products, and processes. The implication is that productivity differences across businesses reflect idiosyncratic factors that are not simply a matter of technologies and that such differences can be pervasive in high tech and low tech sectors and probably more significant in less advanced and emerging economies (Inklaar et al., 2017).

We proceeded along two steps. The first step is the identification of managerial quality or, better to say, the quality of managerial capital. The second step is the search for firms and country determinants of managerial quality. The empirical approach intertwines firms and country. We have two primary sets of results.

First, firm facts show that firms characteristics contribute to managerial quality. Unevenly distributed across countries, they surely contribute to understanding why best management practices are not horizontally adopted across countries. In this case managerial quality is certainly driven by differences in firm attributes. But this is not the whole story, it is only one side of the coin. The other side is that - besides the different distribution of firm attributes, even the location of a firm itself in a specific area (a country) would contribute to explain managerial quality differences. The country-grouping changes, accelerates or dampens the impact of firms' characteristics on management performance so that we can better read the effective channels conducive of better managerial practices. However, this is not surprising because firm managerial quality depends upon the spatially - constrained availability of resources devoted to improve business climate, targeting managerial quality. In short, the higher the attention devoted to business climate improvements, the greater the benefits for local firms. Afterwards, institutional systems are also international business contexts and with the rise of developing economies throughout the global economy, what is crucial is to shed light on the role of institutional context in understudied regions in order to advance knowledge to 
international business as argued by Fainshmidt et al. (2018). The same can be said about the relationship between national and organizational culture and its impact on manufacturing performance in the era of transnational activities (Naor et al., 2010).

The second set of results is about reading the country-firm interplay as the channels through which the context affects the quality of managerial skill. In this case what surprising is the different channel through which the country influences the quality of managerial capital: through participation in global value chain (henceforth GVC) and ownership in less-advanced countries, through the degree of competition, education and technology in high-income countries? In particular, GVC participation significantly enhances managerial quality of firms in low-income countries, acting as balancing strategy under weaker institutional arrangements (Khan et al., 2018). Even when firm heterogeneity and its many features are accounted for by the empirical analysis, some issues remain open and the country-grouping is still intoplay.

The paper is structured as follows. After the sketch of the related literature, Section 3 describes the stylized facts that motivate the analysis. Section 4 details the data and the identification of managerial quality with managerial quality scores (MQSs). Section 5 presents the results of the methodology used to identify the drivers of management practices, by looking at the role of firm and country attributes. Finally, in Section 6 we conclude by looking at policy implications. Appendices are devoted to full data description, management score measurement and results related to the interaction model.

\section{Related Literatures}

This paper relies upon several literatures, organized in three strands across countries: the first considers productivity between and within firms, the second focuses on the drivers of managerial quality, the third looks at managerial incentives and the related training programmes. They are respectively linked to theoretical and empirical underpinnings as well as to their policy implications.

First, the empirical literature relates management practices to productivity and to performance between and within firms: in other words, the starting point is the set of results of the World Management Survey programme that has gained greater coverage of business practices across economies. In this programme, the positive correlations between measures of management practices and firm performance are common so that higher management scores are robustly associated with better performance in manufacturing (Bloom \& Van Reenen, 2010) and non-manufacturing firms. In short, firms which scored more highly in management quality index improved firm performance. Bloom and Van Reenen documented (Note 6) that higher quality management practices are correlated with several measures of productivity and firm performance, including labour productivity, TFP, return on capital Tobins Q, sales growth and the probability of survival. The correlation between a firm's management practice score and its TFP is statistically robust and economically non trivial. For example, surveyed managers from over 700 medium-sized firms in the United States, United Kingdom, France, and Germany revealed that a shift from the lower to the upper quartile of management scores between firms was associated with a very significant increase in TFP (Bloom \& Van Reenen, 2007). More recently, differences in management practices account for about $30 \%$ of total factor productivity gaps, both between countries and within countries across firms (Bloom et al., 2017b). Even different estimates of firm performance equations show that the measure of company's management quality is positively related to different measures of firm performance.

Second, the empirical literature looks for the determinants of managerial practices and the predictors of the quality of management practices within a firm (Bloom \& Van Reenen, 2007). Taking for given the previous result on the positive association between managerial quality and performance, the applied research (Bloom et al., 2017a) on the drivers of management practices has identified many reasons like product market competition, business environment, learning spillovers from large manufacturing plant entry (primarily belonging to multinational corporations), and education. Of course, some of these reasons may be better suited to explaining differences within countries or across industries, while other reasons may be better-suited to explaining difference between countries (Note 7). However, some factors emerge as very important predictors of managerial practice at the firm level: more intense competition, measured in several ways, is surely positively correlated with best- practice management as well as specific characteristics of ownership, like family (Bloom \& Van Reenen, 2007) or multinational ownership. These key factors apparently matter in non-transition countries as well as in transition countries (Bloom et al., 2012), suggesting a horizontal, across- country similarity. But when attention is specifically paid to the channels of management practices in less advanced and emerging countries, competition and ownership play together with business environment, institutional arrangements, learning spillovers and human capital. In this case, 
sectors and countries play a role, suggesting for a cross-country dissimilarity of factors affecting managerial practices. For instance, in emerging countries, business environment plays together with the variety of corporate governance arrangements and their effectiveness (Armitage et al., 2017), often dominated by principal-principal conflicts (Young et al., 2008) between controlling shareholders and minority shareholders. Not only the adoption of international best managerial practices is constrained by the path-dependency or the country specific formal and informal institutions but even the corporate governance mechanisms have less effect when a country's governance system is weaker (Claessens \& Yurtoglu, 2013). More recent empirical research (Bloom et al., 2017a) focuses on across plants comparison, providing evidence on the dispersion of management practices, with $40 \%$ of this variation across plants within the same firm. Despite of this dispersion, it confirms that plants using more structured management practices have successful performance results, like greater productivity, profitability, innovation and growth.

Third, the role of managerial incentives as well as of individual characteristics for managerial quality has been empirically examined. In this strand, the incentives to invest in managerial skills are considered. For instance, the incentives of managers to invest in their skills and the resulting endogenous skill distribution of managers are at the centre of income and productivity differences across countries (Guner et al., 2015). We do not consider this third strand as it requires detailed data on managerial incentives in different context, even though this footpath could be very important for weighting managerial quality differences across countries. We rather pay attention to its policy implications about the right incentives or the training programmes for emerging and transition countries. In other words, on the needs to rebalance policy away from R\&D - centered initiatives - building up firm managerial capabilities in these countries, needed to reap the returns to innovation investments (Cirera \& Maloney, 2017).

We dwell upon what is common to the first and the second strand, that is that firm and country heterogeneity and especially the related firm characteristics are the most important channels of managerial quality and thus of productivity or performance indicators across countries. We con- tribute to the literature by looking not only at the interplay between firm and country determinants of managerial skill but also at the resulting channels conducive of better managerialpractices.

First, the paper measures managerial quality (MQ), calculating management quality scores (MQSs). Second, it shows the firm and country determinants of managerial quality or the drivers of MQ. Third, the paper shows that MQSs are not fully dwarfed by firm characteristics because their weight and significance vary hand by hand with the level of development. Country and country-groups do play a role so that in high and low income countries firm's characteristics matter differently across countries. This country and firm interplay allows for the identification of the channels conducive of better managerial practices. Hence, we contribute to the literature in looking in depth at the heterogeneity of determinants of managerial quality. Taking for given that firms with better practices have higher productivity, sales, and profits, our identification of the channels through which firm and country interact in affecting managerial quality is a way to explain why business practices vary widely across and within countries. If business management skills are important drivers of firm growth, and key determinant of productivity, the identification of these channels of managerial upgrading can be crucial for countries under consideration (Bruhn et al., 2018).

\section{Stylized Facts}

We can mix-up a country perspective and a firm perspective in order to show the stylized facts showing the needs for a proper investigation of managerial quality. From Figure 1 and 2, we observe:

- $\quad$ The distribution by quartiles (Figure 1) shows the positive link between MQSs and the quartile distribution of labour productivity at the firm level, acrosscountries (Note 8).

- A positive correlation between MQSs and labour productivity, looking at the mean values by country in Fig. 2. Nevertheless, very close productivity levels are often associated to different MQSs, with a high dispersion. 


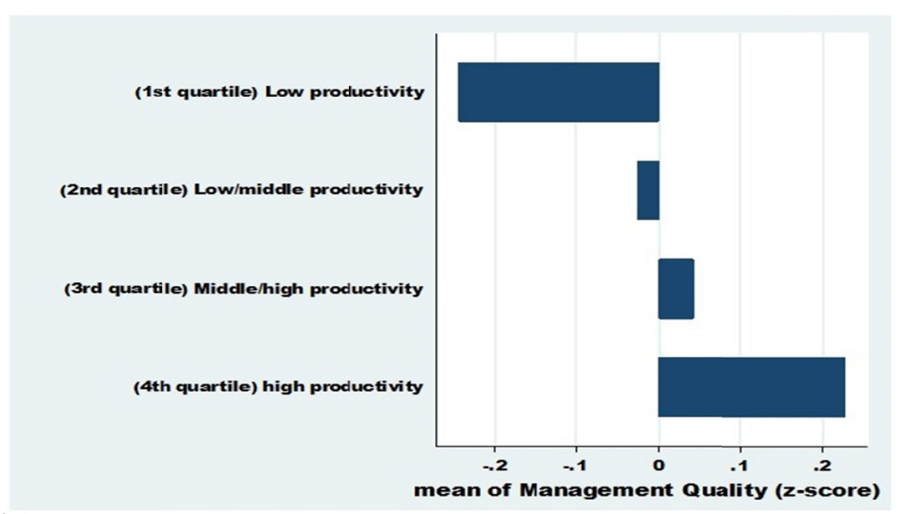

Figure 1. Management quality (MQSs) and quartiles of labour productivity Source: BEEPS V-MENA ES and authors' calculations.

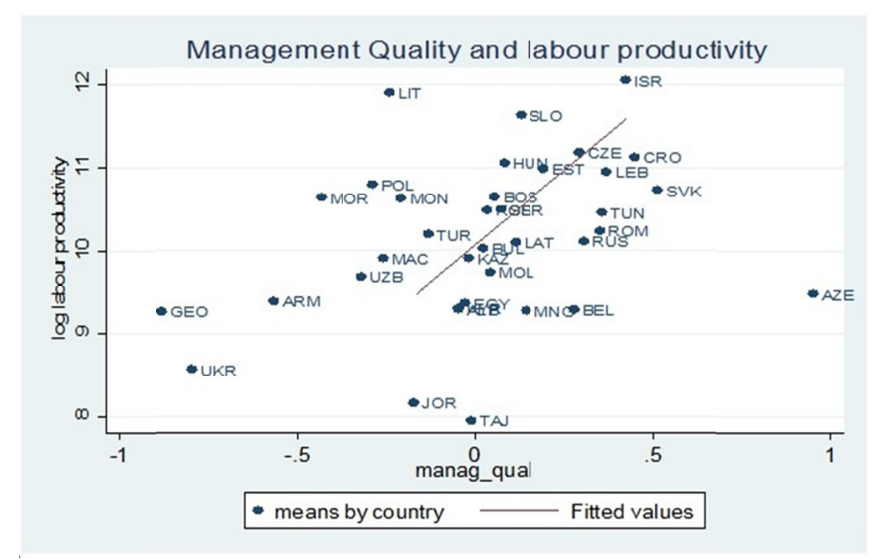

Figure 2. Management quality scores (MQSs) and Labour productivity Source: BEEPS V-MENA ES and authors' calculations.

From Figure 3 and 4 we observe:

- A positive correlation between per capita GDP and MQSs, looking at mean values by country (Figure 3) but for very close GDP level, different MQSs arise.

- At very close per-capita GDP, not only the level but also the distribution of MQSs look very different as in Figure 4. 


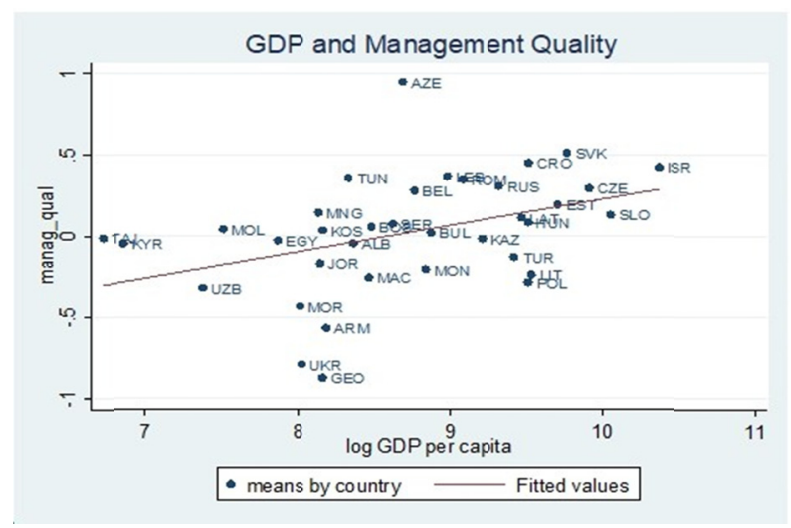

Figure 3. Quality of Management and GDP per-capita

Source: BEEPS V-MENA ES and author' calculations.

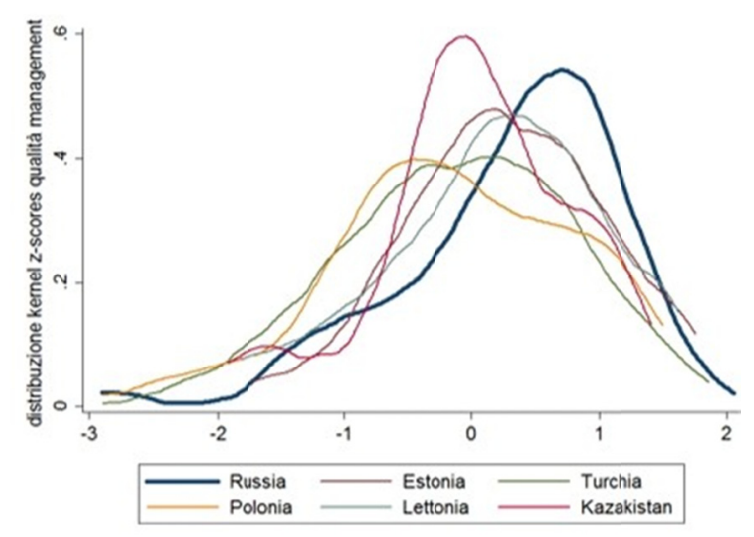

Figure 4. Distributions of MQSs by country (country with very close per-capita GDP)

Source: BEEPS V-MENA ES and authors' calculations.

MQS varies according to productivity (Figure 1) but at the same time, taking for given the average values per country, behind very close productivity levels there are very different MQSs. Large differences in productivity across both firms and countries are well established in the literature, but large differences in managerial quality across both firms (Fig. 1) and countries (Figure 2) exist and require investigation. Using firm data, results are very clearly cut across countries (Figure 1) so that countries and regions under our investigation are not an exception with respect to the results well established in the literature, mostly related to more advanced regions. However, when mean values at the country level are considered (Figure 2) results are less clearly cut and the dispersion across countries becomes more apparent. Country characteristics appear to play a role. There is a positive correlation between per capita GDP and MQSs (Figure 3) but in many cases, for very close GDP level, different MQSs levels and distributions characteristics arise (Figure 4) (Note 9). Therefore, country characteristics are important for MQSs but they are not exhaustive. On one side, they are crucially affecting MQSs and on the other side, firm characteristics play a role because they affect MQSs horizontally across countries. Thus, looking at country and firm level, determinants of managerial quality contribute to detect which country or firm features are central for any policy devoted to business climate and managerial skillimprovement.

\section{Dataset and Management Practices}

We describe the datasets (BEEPS V-MENA ES) in more details in Appendix A, but we sketch out the important features here. BEEPS are a firm-level survey based on face-to-face interviews with managers which examines the quality of the business environment. Firms in Eastern Europe and Central Asia (including Turkey) were surveyed in order to assess the environment for private enterprise and business 
development. BEEPS V involved more than 15,500 interviews with firms in 30 different countries. The Middle East and North Africa Enterprise Surveys (MENA ES) is a firm-level survey covering Middle East and North African countries, inclusive of southern and eastern Mediterranean. The surveys, cross-sectional, were undertaken in 2012-2014 and cover the majority of manufacturing sectors (excluding mining), as well as retail and other sectors, including most service sectors (such as wholesaling, hotels, restaurants, transport, storage, communications and IT) and construction. Only official or registered companies with five employees or more are eligible to participate but data on management practices were asked to establishments with more than 20 employees only (more than 50 in Russia).

\subsection{Measuring Management Practices}

The quality of management is inherently difficult to formalise and measure because it requires codifying the concept of good or bad management into a measure applicable to different firms across countries. This is a hard task as good management is difficult to define and is often contingent on a firm's environment (Note 10). Different indicators of management practices can be thought as indicators of the quality of management, our latent variable. The task of quantifying the quality of management is approached constructing a robust measure of management practices overcoming one hurdle: scoring management practices on the basis of the data available in BEEPS and MENA ES dataset from which survey responses to measure management practices were drawn - as for instance in Bloom et al. (2012) and EBRD (2014). The questions concern four (Note 11) separate aspects of management: operations, monitoring, targets and incentives considered to be essential elements of good management (Note 12).

A standardized score was calculated for each of these aspects on the basis of scores for individual management practices, which were evaluated on the basis of the answers provided to the questions in the survey (details in Appendix B). That is, the average management score across all firms for which the variables are available for all countries is equal to zero. Management quality of individual firms can deviate either left or right from zero, showing below (above) the average managerial practice. While the former indicates below average management practices, obtaining a positive overall z-score refers to a higher quality of management practices. The same applies at country-level or country groupings-level. Bivariate statistics emphasise the positive link between management quality and productivity as shown by the positive correlation between average labour productivity and the average quality of management practices (Figure 1). Countries where the average quality of management is lower have a smaller percentage of firms with good management practices than countries where the quality of management practices tends to be higher.

\section{Drivers of Managerial Quality Results}

\subsection{Drivers of Management Practices: The Role of Firms' Characteristics}

The identification of the drivers of managerial quality implies that both firm and country factors could be important and firm's features could impact differently in different countries. To this purpose, as a first step we estimated an OLS linear regression (Note 13), with robust standard errors because of the presence of heteroskedasticity. The $z$ score of management quality is the dependent variable and the covariates are some firm-level characteristics, identified as affecting managerial quality in the previous literature. The estimated regression equation is as follows:

$$
Y_{i}=F_{i} \beta+M_{i} \gamma+\mathrm{s}_{i}
$$

where $Y_{i}$ refers to MQSs for the firm $i, \mathrm{~F}$ is a vector of variables of firm characteristics, $\beta$ is the vector of their coefficients; $M$ is a vector of variables of manager' $s$ individual characteristics, $\gamma$ is the vector of coefficients $\varepsilon$ the vector of error terms.

Then, to test whether countries are important in determining management quality, we estimated a second regression, adding to previous models the dummy variables for each of the countries where firms are established. This regression equation is:

$$
Y_{i}=F_{i} \beta+M_{i} \gamma+C_{i} \delta+\mathrm{s}_{i}
$$

Which adds to equation (1) the vector $\mathrm{C}$ of the dummy variables for the countries of the sample, being $\delta$ the vector of their coefficients. The results of these two regressions are shown in Table 1, respectively in Column (1) and (2). The covariates are: firm size, education of the workforce, number of competitors, participation in global value chain (henceforth GVC), ownership, techno- logical level of the firm's sector, the age of the firm. The control variables are two individual characteristics of the top manager CEO: his/her gender and the age of experience in that sector (Note 14). 
Firm characteristics matter for management quality as Tab. 1 shows. All firm-level covariates examined in previous literature exert here the expected results on managerial quality. Size, market competition, education, participation in GVC, technology, and ownership, they all show thatbetter management practices are related to larger size, higher competition, significant GVCparticipation, better sectoral technology and education. In some cases, as for size and education, effects are positive but non-linear and in others, as for competition, effects show an inverted U-shape. Participation in GVC looks very important especially for direct exporting firms but not for indirect exporting firms. The difference between the positive and the negative effect of the different exposures to GVC is very pronounced. Foreign ownership shows a positive impact on managerial quality. The age of the firm is not significant here despite of its bivariate positive link with managerial quality for which, as cohorts age, MQS increases (Note 15).

In line with the literature, even in the countries under investigation, firms facing greater competition are more likely to have better management practices. Higher levels of competition are strongly associated with better management practices, at least within the interval of 1 to 10 competitors. This competition effect could arise through a number of channels, including the inducement of greater managerial efforts. These findings are consistent with econometric work looking at the link between higher competition in the cross-section and panel dimension and significant improvements in management quality as well as at the importance of product market competition in increasing productivity. It has often been speculated that the productivity-enhancing effects of competition work through improving average management practices (Bloom \& Van Reenen, 2007), and our study provides support for this view through the effect of competition on managerialquality.

Overall, the results of column (1) show that firm characteristics explain a limited amount of managerial quality, a magnitude which is significantly increased by country effects (column 2). The inclusion of country effects, with country dummy variables, increases significantly: the explanatory power of the model: $R^{2}$ increases from 0.07 to 0.18 (Note 16). This implies that firm-level and country-level variables are both needed to detect factors affecting managerial quality. Thus, in order to investigate the role of country attributes, country groupings can be useful and require further investigation. 
Table 1. Firm characteristics and MQS

\begin{tabular}{|c|c|c|}
\hline & (1) & (2) \\
\hline & MQS & MQS \\
\hline \multirow[t]{2}{*}{ SIZE } & $0.157 * *$ & 0.156 \\
\hline & $(7.43)$ & $(7.42)$ \\
\hline \multirow[t]{2}{*}{ EDUCATION } & 00514* & $0.0862 * * *$ \\
\hline & $(2.50)$ & $(4.16)$ \\
\hline \multicolumn{3}{|l|}{ COMPETITION } \\
\hline \multirow[t]{2}{*}{ competitors_0 } & 0.0851 & 0.0793 \\
\hline & $(0.83)$ & $(0.91)$ \\
\hline \multirow[t]{2}{*}{ competitors_1to5 } & $0.129 * *$ & $0.144 * *$ \\
\hline & $(2.60)$ & $(2.62)$ \\
\hline \multirow[t]{2}{*}{ competitors_6to10 } & $0.223 * * *$ & $0.218 * * *$ \\
\hline & $(3.71)$ & $(3.37)$ \\
\hline \multirow[t]{2}{*}{ competitors_11to50 } & $0.200 * *$ & $0.161^{*}$ \\
\hline & $(2.94)$ & $(2.29)$ \\
\hline \multirow[t]{2}{*}{ competitors_51to 300} & -0.0172 & -0.0356 \\
\hline & $(-0.13)$ & $(0.26)$ \\
\hline \multicolumn{3}{|l|}{ GVC PARTICIPATION } \\
\hline \multirow[t]{2}{*}{$\operatorname{directGVC}$} & $0.173 * *$ & $0.148^{* *}$ \\
\hline & $(3.09)$ & $(2.60)$ \\
\hline \multirow[t]{2}{*}{ indirectGVC } & $-0.277^{*}$ & $-0.245^{*}$ \\
\hline & $(-2.43)$ & $(-2.24)$ \\
\hline \multirow[t]{2}{*}{ dirandindirGVC } & 0.0835 & 0.0467 \\
\hline & $(0.89)$ & $(0.49)$ \\
\hline \multicolumn{3}{|l|}{ OWNERSHIP } \\
\hline \multirow[t]{2}{*}{ foreignprivate } & $0.199 *$ & $0.188^{*}$ \\
\hline & $(2.57)$ & $(2.52)$ \\
\hline \multirow[t]{2}{*}{ domesticpublic } & -0.0274 & 0.0746 \\
\hline & $(-2.43)$ & $(0.53)$ \\
\hline \multirow[t]{2}{*}{ mix_domprivforpriv } & 0.328 & 0.621 \\
\hline & $(1.27)$ & $(1.95)$ \\
\hline \multirow[t]{2}{*}{ mix_domprivdompub } & $0.731 * * *$ & $0.989 * *$ \\
\hline & $(9.00)$ & $(2.61)$ \\
\hline \multicolumn{3}{|l|}{ TECHNOLOGY } \\
\hline \multirow[t]{2}{*}{ mediumhighTech } & $0.154 * *$ & $0.101^{*}$ \\
\hline & $(2.97)$ & $(2.00)$ \\
\hline \multirow[t]{2}{*}{ AGE } & -0.00037 & -0.0015 \\
\hline & $(-0.28)$ & $(-1.17)$ \\
\hline Manager characteristics & YES & YES \\
\hline COUNTRY dummies & NO & YES \\
\hline \multirow[t]{2}{*}{ Constant } & $-1.349 * * *$ & $-1.526^{* * *}$ \\
\hline & $(-9.95)$ & $(-6.03)$ \\
\hline Observations & 2325 & 2325 \\
\hline $\mathrm{R}^{2}$ & 0.0705 & 0.1825 \\
\hline$\left.{ }^{*}\right) \operatorname{Adj} . R^{2}$ & 0.0632 & 0.1634 \\
\hline $\mathrm{F}$ & $\mathrm{F}(18,2036)=17.01$ & $F(35,2271)=10.23$ \\
\hline Prob $>F$ & Prob $>F=0.000$ & Prob $>F=0.000$ \\
\hline VIF & 1.07 & 2.92 \\
\hline
\end{tabular}

Notes. $t$ statistic in parentheses; ${ }^{*} p<0.05,{ }^{* *} p<0.01,{ }^{* * *} p<0.001$; The baselines for categorical variables are: for Competition: too many competitors to count, for GVC participation: no participation to GVC; for Ownership: domestic private ownership; for Technology: low technology.

$(*)$ As OLS with robust SE do not provide Adj. $R^{2}$, it refers to non-robust OLS of the same model. 


\subsection{Drivers of Managerial Practices: The Role of Countries' Characteristics}

Are management practices contingent on the firm's environment? In this case every firm adopts its best practice, given the circumstances. But many aspects of management are not contingent, so that contingency is not the whole story and heterogeneity requires an explanation. The regions considered here are very heterogeneous and country groupings aim to tackle this diversity. Two indicators are selected as criteria to classify countries: first, the per capita income level (Tab. A.1 in Appendix) and second, a proxy for the institutional context, in our case for some of the European countries, the access to European Union. Countries can have an access complete before/after 2007 or be EU candidates or potential EU candidates (details in Table A.2, Appendix A), different status that can characterize firm managerial similarities and differences (Note 17). The other countries outside EU are grouped according to a geographical criterium, with Russia and Israel not included in any group.

The estimated regression equations are now:

$$
Y_{i}=F_{i} \beta+M_{i} \gamma+I_{i} \zeta+\mathrm{s}_{i}
$$

and

$$
Y_{i}=F_{i} \beta+M_{i} \gamma+G_{i} \theta+\mathrm{s}_{i}
$$

They add to Equation (1) respectively the vector I of the dummies representing the group of countries by per-capita income, with the vector $\zeta$ of coefficients, and the vector $G$ of the dummies representing the groups of countries by institutional or geographic characteristics, with the vector $\theta$ of coefficients.

In Table 2, the presence of both the income (column 1) and the institutional criteria (column 2) have a significant impact and the results show that all firm-level covariates display results very close to what Table 1 has already shown. However, when attention is devoted to country groupings, MQSs increase significantly with both income and institutional upgrading. The results show that in the first case (column 1), high income countries show a better managerial quality than the baseline (Upper-middle income countries), whereas the contrary happens for low-middle income. In the second case (column 2), institutional groupings have a significant impact on MQSs. The baseline in this case is the country group entering EU after 2007 (Bulgaria, Croatia and Romania), so that EEC (Eastern European and Caucasian countries), CA (Central Asia) and SEM (Southern and Eastern Mediterranean countries) countries show an impact which is worse than the baseline. Russia and Israel are not significantly different from the baseline. Institutional upgrading seems to matter here. The best performance of MQSs is related to the high income group and to the younger members of the EU or to the most institutionally upgraded group, countries that are new members (after 2007) of the EU. The worst performers are EEC countries (Eastern Europe and Caucasus). From the results in Table 2, both income and the phases of institutional upgrading matter. Furthermore, both columns in table 2 show an interesting increasing explanatory power with respect to Table 1 (column 1). Overall, both income and institutional settings impact more or less equally on managerial quality. Thus, country groupings have a positive link with MQSs, increasing with the level of income and institutional upgrading. The descriptive statistics are consistent with these conclusions: for instance, the mean of MQSs is increasing with increasing per-capita income: from -0.21 , to 0.09 and 0.25 . 
Table 2. Firm and country characteristics and MQS

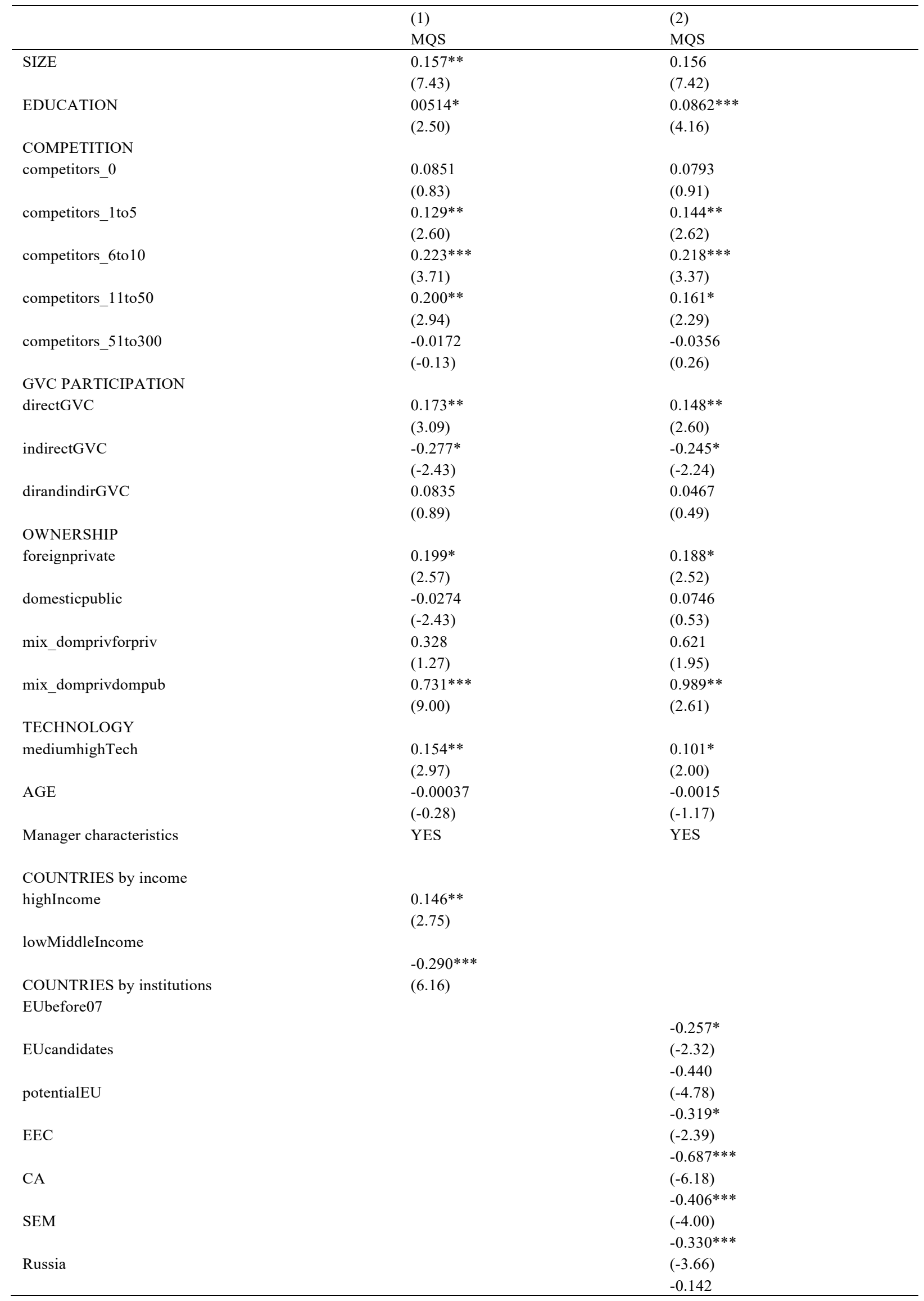




\begin{tabular}{|c|c|c|}
\hline \multirow[t]{2}{*}{ Israel } & & $(-1.43)$ \\
\hline & $-1.167 * * *$ & $0.008 * * *$ \\
\hline \multirow[t]{3}{*}{ Constant } & $(-8.70)$ & $(0.06)$ \\
\hline & & $0.874 * * *$ \\
\hline & & $(-5.87)$ \\
\hline Observations & 2325 & 2325 \\
\hline $\mathrm{R}^{2}$ & 0.0993 & 0.1012 \\
\hline (*) Adj. $R^{2}$ & 0.0915 & 0.0910 \\
\hline $\mathrm{F}$ & $F(20,2304)=13.59$ & $\mathrm{~F}(26,2298)=10.11$ \\
\hline Prob $>F$ & Prob $>F=0.000$ & Prob $>F=0.000$ \\
\hline VIF & 1.13 & 1.86 \\
\hline
\end{tabular}

(*) As OLS with robust SE do not provide Adj. $R^{2}$, it refers to non-robust OLS of the same model.

\subsection{Firm Characteristics in Different Country Groups}

Table 2 suggests that the results of management practices display significant cross-grouping differences as per capita income and institutional country groupings affect significantly MQSs. But the underlying assumptions is that firm covariates impact equally across countries. In search of the country effect, we can relax this assumption, by looking at whether or not the impact of the firm determinants is equal or different in the countries under investigation.

We proceed by simplifying the analysis. First, by looking at the income differences only, leaving aside the institutional criterium. Second, reallocating the countries in two income groups only (Note 18). Furthermore, in order to evaluate the mean difference, we proceed first by distinct regressions for the two income groups and second with a regression for the whole sample with interactions, in which interaction regression coefficients show the difference between the mean scores for high and low-income countries. In other words, we estimated the regression equations

(1) and (2) among the high and low-income countries. In what follows (Table. 3) the results without interaction are reported. Columns (1) and (2) show the results of estimation among high income countries respectively without and with country dummies; columns (3) and (4) indicate the results of estimation among low income countries respectively without and with country dummies. The results for the interaction model are reported in Appendix C(Table C.1).

Table 3 shows that specific firm characteristics impact differently on managerial quality by country groups, a result robust to the introduction of country dummies. In all cases size, as well as foreign ownership, are significant at any income level. Comparing columns (1)-(3) and (2)-(4), most variables are significant in only one of the two groups. Competition, education, and technology are significant for the high income countries only. Direct participation in GVC and the mixed categories of ownership are significant in the low income countries only (Note 19).

The results show that firm characteristics matter differently across country's groups. In the high-income case what matters most are education, technology, competition and foreign ownership. In the low income it is the direct participation in GVC and the mixed ownership that impacts mostly on MQSs. Different firm's attributes play a role by the level of economic development (income) (Note 20). Only firm size and ownership are significant in both groups of countries.

Even the comparison of $R^{2}$ in different estimations (Table 3 can add something: in particular, the explanatory power of the firm characteristics is much more important in high-income than in low-income countries. In the former case, firm characteristics play a bigger role, in the latter case country attributes rather than firm characteristics matter most. What emerges is that not only different firm attributes play a role along the stages of development (proxied by income) but also their weights change alongside, with firm characteristics increasinglyimportant.

These results are coherent with the model with interaction (Appendix C, Tab. C.1). Observing the sign and significance of the interaction terms, we can identify an accelerating effect in high-income countries for education, competition and technology, whereas in low-income the same accelerating effect is played by ownership and participation in GVC. 
Table 3. Firm and country characteristics and MQS (High and Low income countries)

\begin{tabular}{|c|c|c|c|c|}
\hline & (1) & (2) & \multirow{2}{*}{$\begin{array}{l}\text { (3) } \\
\text { MQSLowincome }\end{array}$} & \multirow{2}{*}{$\begin{array}{l}\text { (4) } \\
\text { MQSLowincome }\end{array}$} \\
\hline & \multicolumn{2}{|c|}{ MQSHighincome MQSHighincome } & & \\
\hline \multirow[t]{2}{*}{$\overline{\text { SIZE }}$} & $0.131^{* * *}$ & $0.164^{* * *}$ & $0.152^{* * *}$ & $0.147^{* * *}$ \\
\hline & $(4.52)$ & $(5.32)$ & $(4.95)$ & $(4.92)$ \\
\hline \multirow[t]{2}{*}{ EDUCATION } & $0.116^{* * *}$ & $0.131^{* * *}$ & 0.00389 & 0.0426 \\
\hline & $(4.37)$ & $(4.79)$ & $(0.12)$ & $(1.37)$ \\
\hline \multicolumn{5}{|l|}{ COMPETITION } \\
\hline \multirow[t]{2}{*}{ competitors_0 } & $0.263^{*}$ & 0.148 & -0.166 & 0.00523 \\
\hline & $(2.20)$ & $(1.47)$ & $(-1.01)$ & $(0.04)$ \\
\hline \multirow[t]{2}{*}{ competitors_1to5 } & $0.231^{* * *}$ & $0.232^{* *}$ & -0.0790 & 0.0649 \\
\hline & $(3.37)$ & $(3.18)$ & $(-1.00)$ & $(0.76)$ \\
\hline \multirow[t]{2}{*}{ competitors_6to10 } & $0.268^{* * *}$ & $0.283^{* * *}$ & 0.0617 & 0.195 \\
\hline & $(3.53)$ & $(3.64)$ & $(0.54)$ & $(1.65)$ \\
\hline \multirow[t]{2}{*}{ competitors_11to50 } & $0.314^{* * *}$ & $0.353^{* * *}$ & -0.102 & -0.114 \\
\hline & $(3.55)$ & $(3.84)$ & $(-0.98)$ & $(-1.06)$ \\
\hline \multirow[t]{2}{*}{ competitors_51to300 } & 0.197 & 0.229 & -0.249 & $-0.230 \circ$ \\
\hline & $(0.89)$ & $(0.96)$ & $(-1.61)$ & $(-1.77)$ \\
\hline \multicolumn{5}{|l|}{ GVC PARTECIPATION } \\
\hline \multirow[t]{2}{*}{ directGVC } & 0.0633 & 0.107 & $0.276^{* * *}$ & $0.214 * *$ \\
\hline & $(0.86)$ & $(1.37)$ & $(3.33)$ & $(2.59)$ \\
\hline \multirow{2}{*}{ indirectGVC } & $-0.238^{\circ}$ & -0.215 & -0.284 & -0.218 \\
\hline & $(-1.74)$ & $(-1.53)$ & $(-1.59)$ & $(-1.32)$ \\
\hline \multirow[t]{2}{*}{ dirandindirGVC } & 0.0759 & 0.112 & 0.0153 & -0.157 \\
\hline & $(0.76)$ & $(1.05)$ & $(0.07)$ & $(-0.77)$ \\
\hline \multicolumn{5}{|l|}{ OWNERSHIP } \\
\hline \multirow[t]{2}{*}{ foreignprivate } & $0.238^{*}$ & $0.211^{\circ}$ & $0.202^{*}$ & $0.172^{\circ}$ \\
\hline & $(2.22)$ & $(1.94)$ & $(1.94)$ & $(1.68)$ \\
\hline \multirow[t]{2}{*}{ domesticpublic } & 0.0717 & 0.0896 & 0.107 & 0.147 \\
\hline & $(0.38)$ & $(0.46)$ & $(0.53)$ & $(0.75)$ \\
\hline \multirow[t]{2}{*}{ mix_domprivforpriv } & -0.0439 & -0.0704 & $0.710^{*}$ & $0.968^{*}$ \\
\hline & $(-0.15)$ & $(-0.26)$ & $(2.03)$ & $(2.52)$ \\
\hline \multirow{2}{*}{ mix_domprivdompub } & $0.254^{\circ}$ & 0.164 & $1.160^{* * *}$ & $1.597^{* * *}$ \\
\hline & $(1.88)$ & $(1.15)$ & (11.94) & $(10.68)$ \\
\hline \multicolumn{5}{|l|}{ TECHNOLOGY } \\
\hline \multirow[t]{2}{*}{ mediumhighTech } & $0.155^{*}$ & $0.140^{*}$ & -0.0248 & 0.0327 \\
\hline & $(2.46)$ & $(2.20)$ & $(-0.29)$ & $(0.39)$ \\
\hline \multirow[t]{2}{*}{ AGE } & -0.000446 & -0.000811 & -0.00198 & -0.00282 \\
\hline & $(-0.27)$ & $(-0.49)$ & $(-0.94)$ & $(-1.38)$ \\
\hline Manager characteristics & YES & YES & YES & YES \\
\hline COUNTRY dummies & NO & YES & $\mathrm{NO}$ & YES \\
\hline Constant & $-0.988 * * *$ & $-0.735^{*}$ & $-1.524 * * *$ & $-1.624^{* * *}$ \\
\hline & $(-5.62)$ & $(-2.58)$ & $(-7.27)$ & $(-5.53)$ \\
\hline Observations & 1173 & 1173 & 1152 & 1152 \\
\hline$R^{2}$ & 0.0960 & 0.1775 & 0.0771 & 0.1657 \\
\hline (*) Adj. $R^{2}$ & 0.0819 & 0.1485 & 0.0624 & 0.1434 \\
\hline $\mathrm{F}$ & $F(18,1154)=16.29$ & $F(40,1132)=11.63$ & $F(18,1133)=44.28$ & $F(30,1121)=36.65$ \\
\hline Prob. $>$ F & Prob $>F=0.000$ & Prob $>F=0.000$ & Prob $>F=0.000$ & Prob $>F=0.000$ \\
\hline VIF & 1.12 & 2.51 & 1.07 & 2.34 \\
\hline
\end{tabular}

Notes. $t$ statistic in parentheses; $(p<0.10),{ }^{*} p<0.05,{ }^{* *} p<0.01,{ }^{* * *} p<0.001$; Baselines are the same as in Tab. 1 and 2 .

(*) As OLS with robust SE do not provide Adj. $R^{2}$, it refers to non-robust OLS of the same model.

Two results can now be summarized as follows. First, the analysis of the dataset shows that some important 
firm-level facts, so far unveiled only by country specific studies, hold in this very large cross-section data set, across some parts of Europe, Asia and Northern Africa. This is the case for size and foreign ownership, very important for managerial quality across all samples. Second, the changing relative importance of firm-level characteristics by level of institutional development implies that the channels for improving managerial quality could be very different in more (less) advanced countries. Hence, even the channels for closing the gap between best and average managerial practices must differ. For instance, they should rely upon integrated policies devoted to improving business environment taking into consideration the specific channels through which they are effective.

\subsubsection{GVC Participation by Quintiles}

Results on different drivers of management quality suggest a further investigation devoted to unveil the role of quintiles in explaining the average coefficients of Tab.3 so that the role of the industrial system composition can emerge. In particular, the GVC participation (intended as direct GVC) plays a very important role for different quintiles of MQS. This is not the case for the other variables.

The bivariate analysis in Tab. 4 shows the mean values of MQS by country groupings, by quartiles and by GVC participation. Data show first, the stronger link between MQS and GVC participation in low-income countries, second, that the link is more important for the first and fourth quartiles than for the middle quartiles across all countries and finally, that the strongest link touches the first quartile of the low income countries. In this case, intuition suggests an asymmetry in the relative importance of GVC participation, very important especially for the weaker firms of the lower-income countries, characterized by lower managerial quality.

This intuition is supported by the quintile regression (Table 5) estimating Eq. 4 for different quartiles 0.250 .50 0.75 and testing the differences of the coefficients. In this case, GVC participation shows positive and mostly significant coefficients, an effect clearly driven by the low- income countries, whereas high-income countries show mostly insignificant results. Furthermore, the interquartile differences are significant only for low-income, where the lower quartile drives the result.

This allows for a third result, to be added to the two already summarized at the end of the previous section. Not only firm characteristics matter differently across country's groups. They matter differently even across quartiles, with stronger effects of GVC in lower quartile and significant differences across quartiles, especially in low-income countries.

Table 4. Countries, quartiles and GVC participation

\begin{tabular}{|c|c|c|c|c|c|c|}
\hline & & MQS & 1st Quartile & 2nd Quartile & 3th Quartile & 4th Quartile \\
\hline \multicolumn{7}{|l|}{ ALL } \\
\hline & \multirow[t]{2}{*}{ NOGVC } & -0.069 & -1.359 & -0.246 & 0.401 & 1.146 \\
\hline & & $(n=2998)$ & $(n=802)$ & $(\mathrm{n}=791)$ & $(n=714)$ & $(n=691)$ \\
\hline & \multirow[t]{2}{*}{ GVC } & 0.250 & -1.132 & -0.216 & 0.413 & 1.211 \\
\hline & & $(\mathrm{n}=853 ; 27.1 \%)$ & $(\mathrm{n}=160 ; 16.6 \%)$ & $(\mathrm{n}=170 ; 17.7 \%)$ & $(\mathrm{n}=252 ; 26.1 \%)$ & $(\mathrm{n}=271 ; 28.1 \%)$ \\
\hline & Difference & 0.319 & 0.227 & 0.030 & 0.012 & 0.065 \\
\hline \multirow{5}{*}{$\mathrm{HIGH}$} & \multirow[t]{2}{*}{ NOGVC } & 0.092 & -1.149 & -0.104 & 0.542 & 1.262 \\
\hline & & $(\mathrm{n}=1400)$ & $(n=377)$ & $(\mathrm{n}=358)$ & $(\mathrm{n}=334)$ & $(n=331)$ \\
\hline & \multirow[t]{2}{*}{ GVC } & 0.324 & -1.063 & -0.077 & 0.531 & 1.315 \\
\hline & & $(\mathrm{n}=449 ; 24.3 \%)$ & $(\mathrm{n}=85 ; 18.4 \%)$ & $(\mathrm{n}=102 ; 22,2 \%)$ & $(\mathrm{n}=129 ; 27.9 \%)$ & $(n=133 ; 30.0 \%)$ \\
\hline & Difference & 0.232 & 0.086 & 0.045 & -0.009 & 0.053 \\
\hline \multirow{5}{*}{ LOW } & \multirow[t]{2}{*}{ NOGVC } & -0.209 & -1.524 & -0.356 & 0.262 & 1.011 \\
\hline & & $(\mathrm{n}=1598)$ & $(n=429)$ & $(n=419)$ & $(n=387)$ & $(n=363)$ \\
\hline & \multirow[t]{2}{*}{ GVC } & 0.168 & -1.223 & -0.338 & 0.274 & 1.088 \\
\hline & & $(\mathrm{n}=404 ; 20.1 \%)$ & $(\mathrm{n}=72 ; 14.4 \%)$ & $(\mathrm{n}=80 ; 16.0 \%)$ & $(\mathrm{n}=112 ; 22.4 \%)$ & $(n=140 ; 27.8 \%)$ \\
\hline & Difference & 0.377 & 0.301 & 0.018 & 0.008 & 0.077 \\
\hline
\end{tabular}


Table 5. Coefficients of GVC participation in the quintile regressions

\begin{tabular}{lccc}
\hline & All countries & High income & Low income \\
\hline$\beta$ Coefficients at 0.25 & 0.243 & 0.201 & $0.278^{*}$ \\
& $(1.90)$ & $(1.05)$ & $(2.37)$ \\
$\beta$ Coefficients at 0.50 & $0.173^{*}$ & $0.209^{* *}$ & $0.251^{*}$ \\
& $(2.52)$ & $(3.08)$ & $(2.10)$ \\
$\beta$ Coefficients at 0.75 & 0.034 & 0.096 & -0.016 \\
& $(0.58)$ & $(1.50)$ & $(-0.16)$ \\
\hline Observations & 2325 & 1173 & 1152 \\
Pseudo $R^{2}$ at 0.25 & 0.1127 & 0.1238 & 0.1048 \\
Pseudo $\mathrm{R}^{2}$ at 0.50 & 0.1135 & 0.1246 & 0.0853 \\
Pseudo $\mathrm{R}^{2}$ at 0.75 & 0.1000 & 0.1144 & 0.0844 \\
Test for equal coefficients & $\mathrm{F}(2,2271)=2.25$ & $\mathrm{~F}(2,1132)=2.25$ & $\mathrm{~F}(2,1121)=3.32$ \\
\hline
\end{tabular}

\section{Discussion and Conclusion}

Researchers have long proposed that managers drive productivity differences (Note 21) but managerial quality as potential driver faced significant measurement problems. Efforts on how to measure MQ are underway and today the reasons behind large heterogeneity in managerial quality across countries, firms and plants can be investigated. This is important for countries we consider in this paper not only because they belong to relatively understudied regions but also because many diverse efforts have been recently devoted to improve the business environment, with very mixed effects in multiple cases, as documented in various Subnational Doing BusinessReports.

Unlike most of the previous research, the present paper concentrates on factors that affect managerial quality and pays special attention to the country-firm interplay as conducive of better managerial practices. An empirical approach is adopted here that simultaneously considers both country factors (i.e. per capita income or institutional settings), and firm factors (i.e. firms' characteristics). The latter are captured by firms' structural variables or firms attributes, while the former are captured by characteristics of national systems. Such an approach leads to a comprehensive analysis of the topic and is particularly useful to highlight cross-national and cross-firm disparities in the MQSs. The econometric analysis is conducted on a large sample of manufacturing and service firms derived from BEEPS V-MENA ES and on some European and a number of Asian and Northern-African countries.

In line with some previous studies, the results confirm the important role of firms structural characteristics on managerial quality. Overall, firms operating with larger size, foreign and mixed ownership, better skilled workforce, facing intermediate degree of competition and working in upper technological sectors display better managerial practices but this relationship appears more complex than typically shown because of the interaction with the country level ofdevelopment.

In addition to previously studied firms features, this paper shows that not only micro structural features but also national systems play an important role for managerial quality. Countries differences are captured by both institutional upgrading and per capita income, both conducive of higher MQs. In particular, the econometric analysis suggests that firm characteristics supporting managerial practices act differently in high and low income countries with significant cross-country disparities. Size and foreign ownership play across all countries; participation in GVC and mixed ownership are important for low income countries only, whereas education and competition are significant for high income countries only. Not only firm characteristics play differently across country's group with dampening or accelerating effects on managerial quality. They matter differently even across quartiles, with stronger effects of GVC in lower quartile and significant differences across quartiles, especially in low income countries.

This implies that governments, rule makers and practitioners may need to act differently in order to improve business environment, stimulate managerial upgrading and encourage the determinants of this upgrading by reckoning the complementarities between national policies and targeted firm policies. For instance, in the low-income country case, targeted policies at the firm level must be devoted to increasing GVC participation (World Bank, 2020) and to choose the proper mixing-up of ownership. In particular. the 
weaker firm management benefits from GVC participation that accelerates significantly managerial quality. In the high-income country case, competition, education and technology are the most important vehicles for managerial quality and GVC participationdoes not play any significant role formanagement.

This has some policy implications. Implications that go back to our economic premise and stress the importance of managerial upgrading. If managerial and business practices are important predictor of productivity differences across countries and between firms, then managerial upgrading could contribute to face the capability and market failures, that in case of many developing and transition countries are a well-recognized source of the "middle-income trap" (Stiglitz et al., 2013).

The first implication makes the most of the interweaving between country-specific and firms characteristics. In light of the increasing number of economists arguing that a passive industrial policy is not today the best policy option for growth (Aghion et al., 2011), our results suggest that any kind of non-passive industrial policy has to deal with the interactive building blocks, at the national and firm level. This requires a holistic approach (Note 22) addressing the issues of performance and competitiveness along with improving regulatory frameworks and the business environment and reinforcing institutional capacities of technical and business support. The reliance solely upon national industrial policies is ineffective, as there are important cross-country spillovers suggested by cross-country micro characteristics and their interactions. But micro characteristics do not simply act horizontally across countries. They are affected differently by the country groupings, at different stages of development, so that even interventions at the enterprise level alone, do not produce optimal results without addressing the issues related to the context, the overall business environment and the role of formal and informalinstitutions.

The second implication is about the role of the training programmes devoted to cope with the weak managerial and business practices (Bruhn et al., 2018) in developing countries and economies in transition, especially in the case of weaker enterprises. They often lack managerial capacities and have insufficient knowledge of business processes, organizational innovations as well as of operational and production cycles. Managerial and organizational practices are weak, especially those required to pursue innovation and take it to market successfully (Cirera \& Maloney, 2017). Management matters even for micro enterprises, where in some cases the majority of the labour force works (McKenzie \& Woodruff, 2016). Evidence from several training programmes in microenterprises in some developing countries concludes that most of the training programmes have insignificant impacts on outcomes due to the missing impacts (McKenzie \& Woodruff, 2014) on improvement of business practices. By how much this is due to the insufficient attention to the country, firm and channel specificity is still an open question.

Within any country, there is big scope for productivity improvement by closing the gap between best practices and average practices of managerial quality. But the channels are different and asymmetric, probably the result of the evolution of the country-specific formal and informal institutions so that using policies designed for developed economies may prove ineffective or even counterproductive in transition and emerging economies. In all cases, it is the complementarity between business environment reforms devoted to managerial upgrading and policy targeted to enhance firms best performing characteristics that can support the adoption of best managerial practices. This complementarity is possible only when the asymmetric channels more conducive of better managerial practices are identified, in presence of an adequate corporate governance system.

\section{Acknowledgements}

We thank Giuseppe Lubrano-Lavadera and Cristian Roner for helpful comments and suggestions. We would also like to thank participants at Prato Workshop, June 7-8 2018, XV Meeting cMET05 and at the Rome SIEPI Workshop (January 29 - February 1, 2019) for useful discussions. Special thanks to Irene Fiorio who undertook a side project analysis.

\section{References}

Aghion, P., Boulanger, J., \& Cohen, E. (2011). Rethinking industrial policy. Bruegel Policy Brief. Retrieved from https://bruegel.org/2011/06/rethinking-industrial-policy/

Armitage, S., Hou, W., Sarkar, S., \& Talaulicar, T. (2017). Corporate governance challenges in emerging economies. Corporate Governance, 25, 148-154. https://doi.org/10.1111/corg.12209

Athanasouli, D., \& Goujard, A. (2015). Corruption and management practices: Firm level evidence. Journal of Comparative Economics, 43, 1014-1034. https://doi.org/10.1016/j.jce.2015.03.002

Bartelsman, E., Haltiwanger, J., \& Scarpetta, S. (2013). Cross-country differences in productivity: The role 
of allocation and selection. American Economic Review, 103(1), 305-334. https://dx.doi.org/10.1257/aer.103.1.305

Bartz, W., Mohnen, P., \& Schweiger, H. (2016). The role of innovation and management practices in determining firm productivity: Evidence from transition economies. EBRD Working Paper, 188.

Bloom, N., \& Van Reenen, J. (2007). Measuring and explaining management practices across firms and countries. The Quarterly Journal of Economics, 122(4), 1351-1408. https://doi.org/10.1162/qjec.2007.122.4.1351

Bloom, N., \& Van Reenen, J. (2010). Why do management practices differ across firms and countries? Journal of Economic Perspectives, 24(1), 203-224. https://doi.org/10.1257/jep.24.1.203

Bloom, N., Brynjolfsson, E., Foster, L., Jarmin, R., Patnaik, M., Saporta-Eksten, I., \& Van Reenen, J. (2017). What drives differences in management? NBER WP Series, 23300. Retrieved from https://www.nber.org/papers/w23300

Bloom, N., Eifert, B., Mahajan, A., McKenzie, D., \& Roberts, J. (2013). Does management matter? Evidence from India. The Quarterly Journal of Economics, 128(1), 1-51. https://doi.org/10.1093/qje/qjs044

Bloom, N., Genakos, C., Martin, R., \& Sadun, R. (2010). Modern management: Good for environment of just hot air. The Economic Journal, 120(544), 551-572. https://doi.org/10.1111/j.1468-0297.2010.02351.x

Bloom, N., Sadun, R., \& Van Reenen, J. (2017b). Management as technology. NBER WP Series, 22327. https://www.nber.org/papers/w22327

Bloom, N., Schweiger, H., \& Van Reenen, J. (2012). The land that lean manufacturing forgot? Economics of Transition, 20(4), 593-635. https://doi.org/10.1111/j.1468-0351.2012.00444.x

Bruhn, M., Karlan, D., \& Schoar, A. (2018). The impact of consulting services on small and medium enterprises: Evidence from a randomized trial in Mexico. Journal of Political Economy, 126(2), 635-687. https://dx.doi.org/10.1086/696154

Cirera, X., \& Maloney, W. F. (2017). The innovation paradox. Developing-country capabilities and the unrealized promise of technological catch-up. Technical report, World Bank Group. Retrieved from http://hdl.handle.net/10986/28341

Claessens, S., \& Yurtoglu, B. (2013). Corporate governance in emerging markets: A survey. Emerging Markets Review, 15, 1-33. https://doi.org/10.1016/j.ememar.2012.03.002

EBRD. (2014). Transition Report 2014: Innovation in Transition. Technical Report, London. Retrieved from https://www.ebrd.com/news/publications/transition-report/transition-report-2014.html

Fainshmidt, S., Judge, W. Q., Aguilera, R. V., \& Smith, A. (2018). Varieties of institutional systems: a contextual taxonomy of understudied countries. Journal of World Business, 53(3), 307-322.

Fowler, R., Mattos, H. G. D., \& Chapman, M. (2018). Adapting adaptation: expanding adaptive strategy theory to account for the East Asian business context. Journal of World Business, 53, 323-336. https://doi.org/10.1016/j.jwb.2017.06.008

Friebel, G., \& Schweiger, H. (2013). Management quality, ownership, firm performance and market pressure in Russia. Open Economies Review. https://dx.doi.org/10.2139/ssrn.2180448

Goedhuys-Degelin, M., Mohnen, P., \& Tamer, T. (2016). Corruption, innovation and firm growth: firm level evidence from Egypt and Tunisia. Eurasian Business Review, 6(3), 299-322. https://doi.org/10.1007/s40821-016-0062-4

Guner, N., Parkhomenko, A., \&Ventura, G. (2015). Managers and productivity differences. CEPR Discussion Paper $\quad 11012 . \quad$ Retrieved from http://www.cepr.org/active/publications/discussion_papers/dp.php?dpno=11012

Hsieh, C. T., \& Klenow, P. J. (2009). Misallocation and manufacturing TFP in China and India. The Quarterly Journal of Economics, 124(4), 1403-1448. https://doi.org/10.1162/qjec.2009.124.4.1403

Inklaar, R., Lashitew, A. A., \& Timmer, M. P. (2017). The role of resource misallocation in cross- country differences in manufacturing productivity. Macroeconomics Dynamics, 21(3), 733-756. https://doi.org/10.1017/S1365100515000668 
Khan, Z., Rao-Nicholson, R., \& Tarba, S. Y. (2018). Global networks as a mode of balance for exploratory innovations in a late liberalizing economy. Journal of World Business, 53(3), 392-402. https://doi.org/10.1016/j.jwb.2016.10.002

Litvinova, M., \& Segnana, M. L. (2018). Management quality, business liberal- ization and corruption. the case or Turkey. In B. Dallago \& E. Tortia (Eds.), Entrepreneurship and Local Economic Development: A Comparative Perspec- tive on Entrepreneurs, Universities and Governments. Routledge. Retrieved from https://www.oecd-ilibrary.org/urban-rural-and-regional-development/entrepreneurship

McKenzie, D., \& Woodruff, C. (2014). What are we learning from business training evaluations around the developing world? World Bank Research Observer, 29(1), 48-82. Retrieved from https://elibrary.worldbank.org/doi/abs/10.1093/wbro/lkt007

McKenzie, D., \& Woodruff, C. (2016). Business practices in small firms in developing countries. Management Science, 63(9), 967-981. https://doi.org/10.1287/mnsc.2016.2492

Naor, M., Linderman, K., \& Schroeder, R. (2010). The globalization of operations in Eastern and Western countries: Unpacking the relationship between national and organizational culture and its impact on manufacturing performance. Journal of Operations Management, 28(3), 194-205. https://doi.org/10.1016/j.jom.2009.11.001

Stiglitz, J. E., Yifu, J., \& Monga, C. (2013). The rejuvenation of industrial policy. Research Working Paper, 6628. https://doi.org/10.1016/j.jom.2009.11.001

Syverson, C. (2011). What determines productivity. Journal of Economic Literature, 49(2), 326-65. https://doi.org/10.1257/jel.49.2.326

Waldman, D., de Luque, M. S., \& Wang, D. (2012). What can we really learn about management practices across firms and countries? Academy of Management Perspectives, 26(1), 34-40. https://doi.org/10.5465/amp.2011.0093

World Bank (2020). World Development Report. Trading for Develop- ment in the age of Global Value Chains. Technical Report, World Bank. Retrieved from https://www.worldbank.org/en/publication/wdr2020

Young, M. N., Peng, M. W., Ahlstrom, D., Bruton, G. D., \& Jiang, Y. (2008). Corporate governance in emerging economies: A review of the principal-principal perspective. Journal of Management Studies, 45, 196-220. https://doi.org/10.1111/j.1467-6486.2007.00752.x

\section{Notes}

Note 1. The question on how cross-country differences in economic outcomes relates to differences in the within-industry productivity dispersion across firms opens a large literature on the interplay between the heterogeneity in firm-level productivity, the business environment, and aggregate economic performance. Measures of firm heterogeneity detect possible misallocation as for instance by Hsieh \& Klenow (2009) and Bartelsman et al. (2013).

Note 2. In particular Bloom et al. (2017b) find that about a quarter of cross-country differences in productivity can be attributed to differences in management practices.

Note 3. Using World Bank survey data for formal manufacturing firms in 52 low and middle income countries, Inklaar et al. (2017) show that by reducing misallocation, manufacturing productivity would increase significantly, but productivity differences remain large. This suggests a crucial role for institutional factors.

Note 4. The differences between self-provided scores of managerial quality against actual, objectively measured scores reveal that most managers in many countries are unaware that their own management practices are poor. There are many examples of Managers' surveys using various assessments of overconfidence. This large gap or the cognitive bias is used in the behavioral literature looking at the effects on managerial decision makings, corporate decisions and performance.

Note 5. Transition regions are examined by EBRD Transition Reports and have been studied by Bloom et al. (2012). How management quality explains Russian firm performance is analyzed by Friebel \& Schweiger (2013). The impacts of management practices and innovation on productivity, using BEEPS data, are examined by Barz et al. (2016).

Note 6. See for instance Bloom et al. (2010), Bloom et al. (2013). The same message comes from the literature on knowledge management even when Community Innovation Survey is utilized. 
Note 7. Bloom \& Van Reenen (2007) showed that although $42 \%$ of the overall variation in management practices can be ascribed to country and/or three-digit industry effects, the remaining $56 \%$ is within country and industry.

Note 8. The Pearsons correlation between the management z-score and the log of labour productivity is 0.17 , significant at 0.01 level of confidence.

Note 9. Ease of Doing Business in Russia reached an all time high of 124 in 2010 and a record low of 31 in 2018. It started decreasing in 2012, the year in which the survey was completed in Russia.

Note 10. Cross-cultural and methodological considerations must be taken into account Waldman et al. (2012).

Note 11. For the purpose of comparison, the survey used in Bloom et al. (2017a) contains 16 management questions in three main sections: monitoring, targets and incentives. In BEEPS V-MENA ES surveys, management practices are organized along 12 management questions in four sections.

Note 12. There is scope for legitimate disagreement over whether all of the measures really constitute good practice in different environments.

Note 13. With OLS estimation in a cross-section sample the problem of endogeneity arises, especially for the firm size, the education of the workforce and the number of competitors. We are well aware of this problem and of the constraints about using cross-section data on very understudied regions. Some comments can be added. The aim of the paper is not to quantify the strength of different channels affecting management quality but to focus on whether or not i) the country specificity matters, besides firm characteristics, in explaining management quality; ii) by country-grouping, firm characteristics affect differently managerial quality. The first question is not severely affected by endogeneity: the firm level variables explain in part the variation of firm management, the country dummies significantly increase the ratio of explained variability of the management quality. Even in presence of likely overestimation, the contribution of the country dummies is not substantially affected by the endogeneity bias. About the second question, it would be severely biased if we supposed a differential effect of the endogeneity in the two country groups. Thus, the magnitude of the effects of some variables on management quality could be affected by endogeneity, so that it would be more precise to talk about association among variables rather than causality but the more interesting and innovative results of our paper are unlikely to be strongly affected by the endogeneity problem.

Note 14. In Appendix A, the definition of the variables, the descriptive statistics and the bivariate analysis.

Note 15. In Appendix A Tables A.5 shows the Pearson correlations among the z-score of management quality and the continuous variables included in the regressions, showing that the direction and the significance of the relationships are consistent with the results of the multivariate analysis. The only exception is age.

Note 16. The adjusted $R^{2}$ of the OLS non-robust estimation of the same model increases from 0.06 to 0.16 with the inclusion of country dummy variables.

Note 17. Our reference was the EU Acquis Communautaire. We are aware that context is not adequately addressed in our proxies for institutional differences. The need to go in depth about the degree of contextualization is well underlined by Fowler et al. (2018) among many others, outlining that any kind of operations management decisions need to take culture into account (Naor et al., 2010).

Note 18. See Table A.1 in the Appendix A.

Note 19. Foreign ownership is significant at 0.05 level of confidence only in the model without country dummies for high income countries; in the other three models this variable is significant at 0.10 level of confidence only. In the comment above we did not mention the variable that are significant at 0.10 level in only one of the four models.

Note 20. In Appendix A, Table A6 and A7 show the Pearson correlations among the z-score of managerial quality and the continuous variables included in the regressions, in the low and high income countries. Table A8 reports the mean values of the z-score of managerial quality in all countries (column 1), in high income (column 2) and low income countries (column 3). The results are consistent with those emerging from the multivariate analysis. Firm's age is an exception, as in bivariate analysis for high income countries, it is significantly correlated with MQS, while the regression does not significantly confirm such link. It is also remarkable that, in high income countries, firms with public domestic ownership show the highest 
mean value of MQS, while, according to the results of the regressions result, the firms with private foreign ownership have the best MQSs performance.

Note 21. Chad Syverson quoted Francis A. Walker (1887): [..] managerial ability is the source of differences in surplus across businesses [...].

Note 22. This is crucial according to the UNIDO's Industrial Upgrading and Modernization Programme, applied to developing countries and economies in transition.

\section{Appendices}

Appendix A. Data, variables and descriptive statistics The BEEPS V-MENA ES Datasets

The Business Environment and Enterprise Performance Survey (BEEPS) is a joint initiative con- ducted by the EBRD and the World Bank. BEEPS is a firm-level survey based on face-to-face interviews with managers which examines the quality of the business environment. It was first undertaken in 1999-2000, when approximately 4,100 firms in 25 countries in eastern Europe and Central Asia (including Turkey) were surveyed in order to assess the environment for private enterprise and business development. It has since been conducted every three to four years or so. The recent fifth round of the survey (BEEPS V) was completed in 2012 in Russia and 2014 in all other countries. BEEPS V involved more than 15,500 interviews with firms in 30 different countries. The Middle East and North Africa Enterprise Surveys (MENA ES) are a joint initiative administered by the World Bank, the EBRD and the European Investment Bank (EIB). They were first conducted in selected MENA countries in 2013 and 2014. The surveys cover the countries of the southern and eastern Mediterranean - namely Egypt, Jordan, Morocco and Tunisia - as well as Djibouti, Israel, Lebanon and Yemen. Both surveys cover the majority of manufacturing sectors (excluding mining), as well as retail and other sectors - including most service sectors (such as wholesaling, hotels, restaurants, transport, storage, communications and IT) and construction. Only official-registered-companies with five employees or more are eligible to participate. The survey is conducted at an establishment level, even though some questions (like those about the ownership) concern the firm the establishment belongs to. In some larger economies (such as Russia, Turkey and Ukraine) the survey is representative across additional subsectors for some of the sectors that make the largest contributions to employment and value added. Firms that are wholly owned by the state are not eligible to participate.

\section{Countries in BEEPS V-MENA ES surveys}

- BEEPS countries: Albania, Armenia, Azerbaijan, Belarus, Bosnia and Herzegovina, Bulgaria, Croatia, Czech Republic, Estonia, Georgia, Hungary, Kazakhstan, Kyrgyz Republic, Kosovo Montenegro, Lithuania, Latvia, FYR Macedonia, Moldova, Mongolia, Montenegro, Poland, Russian Federation, Romania, Serbia, Slovak Republic, Slovenia, Tajikistan, Turkey, Ukraine, Uzbekistan.

- $\quad$ MENA countries: Egypt, Israel, Jordan, Lebanon, Morocco, Tunisia (The MENA-ES survey was also conducted in Greece, Cyprus, Djibouti, Yemen, and West Bank and Gaza, but these countries are not considered here).

Data are about 17,133 manufacturing firms but those about Management Quality were asked to establishments with more than 20 employees (more than 50 employees in Russia). Therefore, the largest part of the statistical analysis in this paper is conducted over 3,948 manufacturing firms only. The unit of the statistical analysis is the establishment. The survey is defined as at firm-level, conducted at an establishment level, even though some questions concern the firm the establishment belongs to. It is not possible to reconduct establishment data at the firm level. Because of this, no analysis is developed on between-firm versus between-plant (or establishment).

\section{List of variables}

- QUALITY of MANAGEMENT PRACTICE. We considered all the questions but one in the section $\mathrm{R}$, dedicated to the managerial practices, of the Innovation Module (Questions R.1, R.6, R.7, R.8, R.11, R.13, R.15). The construction of the normalized management quality score (MQS) is described in the Appendix B of this paper.

- $\quad$ SIZE. It is the logarithm of the number of permanent, full-time employees working in the establishment (Question L.1 of the Manufacturing Module).

- EDUCATION. It is the logarithm of the percentage of permanent, full-time university gradu- ated 
employee working in the establishment (Question Q.69 of the Manufacturing Module).

- Number of COMPETITORS in the main market of the establishment. This information is drawn from Question E.2 of the Manufacturing Module. As the effect of the number of competitors on management quality is not linear neither quadratic, we built some dummy variables representing intervals of number of competitors. One of the answers to the question about the number of competitors is too many competitors. This is the baseline for this variable.

- GLOBAL VALUE CHAIN. According to the methodology proposed in Transition Report of 2014 (EBRD, 2014), an establishment is considered to belong to a GVC if it imports from abroad at least $10 \%$ of its total inputs and if it exports at least $10 \%$ of its total output. Then, among the firms participating in a GVC, three categories were identified: firms that make only direct exports (direct GVC); firms that make only indirect exports (indirect GVC); firms that make both direct and indirect exports (dirandindirGVC). Firms not participating in a GVC are the baseline for this variable. Variables are drawn from the answers to questions

D. 3 and D.12 of the Manufacturing Module.

- OWNERSHIP. This information is at the firm level (Question D.2 of the Manufacturing Module). We identify five typologies of firms on the basis on the prevalent percentage among the different categories: Domestic and private, Foreign and private (foreignprivate), Domestic and public (domesticpublic) and two mixed categories: Domestic and foreign private (mix_domprivforpriv), Domestic private and public (mix_domprivforpriv). Domestic private firms are the baseline for thisvariable.

- TECHNOLOGY. The sampling plan kept into account the industrial sector of the establish- ment (Section A.4 of the Manufacturing Module). The Transition Report of 2014 (EBRD, 2014) classified the manufacturing sectors in three technological levels (High and medium, Medium-tech and Low-tech sectors). In the regression analysis the first two levels are merged, therefore we have high and medium tech sectors (Medium high Tech) and low tech sectors, which are the baselines.

- $\quad$ AGE. The age of the firms is obtained subtracting from the year of the interview (2012) the year when the establishment began operations (Question B.5 of the Manufacturing Module).

- MANAGEMENT CHARACTERISTICS. Experience of the top manager and gender.

- EXPERIENCE. It is the logarithm of the years of experience of the top manager in the sector of the establishment (Question B.7 of the Manufacturing Module).

- $\quad$ GENDER. It is the sex of the Top Manager (Question B.7a of the Manufacturing Model).

- COUNTRIES by Income: see Tab.A.1 in the Appendix for details. In the regression reported in Table 2, Column (1), countries are divided in three groups according to their per-capita income: High income countries (high Income), upper-middle income countries and low-middle income countries (low Middle Income); the upper-middle income countries are the baselines. For the following analysis countries are grouped in two groups: high-income countries (highGDP) and low income countries: the variable high GDP is used in the regression with interaction reported in Appendix C.

- $\quad$ COUNTRIES by institutions: see Tab. A2 in this Appendix for details. In the regression reported in Table 2, Column (2), countries are divided in seven groups according to their institutional or geographic situation: Admission to EU before 2007 (EUbefore07); Admission to EU after 2007; Candidates for admission to EU (EUcandidates); Potential candidates (potentialEU); Eastern Europe and Caucasus (EEC); (CA); South and Eastern Mediterranean (SEM); there are also the dummy variables for Russia and Israel; countries admitted to EU after 2007 are the baseline of theregression. 
Table A.1. Composition of sample with income category of countries

\begin{tabular}{|c|c|c|c|c|}
\hline Countries & Nr.of Manuf.firms & Nr.of firms with MQ data & $(*)$ & $(* *)$ \\
\hline Albania & 360 & 248 & $\mathrm{UM}$ & $\mathrm{H}$ \\
\hline Azebaijan & 285 & 64 & $\mathrm{UM}$ & $\mathrm{H}$ \\
\hline Belarus & 285 & 64 & UM & $\mathrm{H}$ \\
\hline Bosnia Herzegovina & 297 & 51 & $\mathrm{UM}$ & $\mathrm{H}$ \\
\hline Bulgaria & 273 & 47 & UM & $\mathrm{H}$ \\
\hline Croatia & 322 & 52 & HI & $\mathrm{H}$ \\
\hline Czech Republic & 217 & 55 & HI & $\mathrm{H}$ \\
\hline Estonia & 243 & 30 & $\mathrm{HM}$ & $\mathrm{H}$ \\
\hline FYR Macedonia & 346 & 51 & UM & $\mathrm{H}$ \\
\hline Hungary & 197 & 25 & $\mathrm{UM}$ & $\mathrm{H}$ \\
\hline Israel & 438 & 107 & UM & $\mathrm{H}$ \\
\hline Kazakhstan & 430 & 88 & $\mathrm{UM}$ & $\mathrm{H}$ \\
\hline Latvia & 270 & 44 & HI & $\mathrm{H}$ \\
\hline Lebanon & 483 & 98 & $\mathrm{UM}$ & $\mathrm{H}$ \\
\hline Lithuania & 225 & 48 & HI & $\mathrm{H}$ \\
\hline Montenegro & 102 & 11 & $\mathrm{UM}$ & $\mathrm{H}$ \\
\hline Poland & 392 & 58 & HI & $\mathrm{H}$ \\
\hline Romania & 476 & 85 & UM & $\mathrm{H}$ \\
\hline Russia & 3,030 & 365 & HI & $\mathrm{H}$ \\
\hline Serbia & 333 & 42 & $\mathrm{UM}$ & $\mathrm{H}$ \\
\hline Slovak Republic & 173 & 32 & HI & $\mathrm{H}$ \\
\hline Slovenia & 244 & 36 & HI & $\mathrm{H}$ \\
\hline Turkey & 839 & 425 & $\mathrm{UM}$ & $\mathrm{H}$ \\
\hline Total high income countries & 10223 & 1914 & & \\
\hline Armenia & 245 & 37 & LM & $\mathrm{L}$ \\
\hline Egypt & 2,457 & 934 & $\mathrm{UM}$ & $\mathrm{L}$ \\
\hline Georgia & 289 & 49 & LM & $\mathrm{L}$ \\
\hline Jordan & 548 & 174 & UM & $\mathrm{L}$ \\
\hline Kyrgyz Rep. & 215 & 49 & LM & $\mathrm{L}$ \\
\hline Kosovo & 179 & 27 & LM & $\mathrm{L}$ \\
\hline Moldova & 312 & 36 & LM & $\mathrm{L}$ \\
\hline Mongolia & 324 & 59 & LM & $\mathrm{L}$ \\
\hline Morocco & 374 & 98 & LM & $\mathrm{L}$ \\
\hline Tunisia & 580 & 243 & $\mathrm{UM}$ & $\mathrm{L}$ \\
\hline Tajikistan & 253 & 24 & LM & $\mathrm{L}$ \\
\hline Ukraine & 769 & 237 & LM & $\mathrm{L}$ \\
\hline Uzbekistan & 365 & 67 & $\mathrm{LM}$ & $\mathrm{L}$ \\
\hline Total low income countries & 6919 & 2034 & & \\
\hline TOTAL & 17133 & 3948 & & \\
\hline
\end{tabular}

Notes. $\left(^{*}\right)$ High(HI), UpperMiddle(UM) and LowMiddleIncome (LM) countries; (**) High and Low income countries;

$\left(^{*}\right)$ Income/region categories are from the World Bank lending group definitions for 2012. This classification is utilized for results in Tab. 2 of the text. (**) In the low income group (L) of this column all the World Bank countries with low-middle income (LM) and the two poorest countries (lowest GDP per capita) of the upper-middle income group (Jordan and Tunisia) are grouped. In the high income (H) all the World Bank high income (HI) and upper-middle (UM) income countries, except Jordan and Tunisia, are grouped. This classification is utilized for results in Tab. 3 of the text. 
Table A.2. Countries by institutional or geographic groupings

\begin{tabular}{llccc}
\hline Country groupings & No. countries & No. Manuf. Firms & No. of firms with reported MQ \\
\hline 1 & Admission to EU before 2007 & 8 & 1961 & 334 \\
2 & Admission to EU after 2007 & 3 & 1071 & 184 \\
3 & Candidates for admission to EU & 5 & 1980 & 1081 \\
4 & Potential candidates & 2 & 476 & 78 \\
5 & Eastern Europe and Caucasus & 6 & 2148 & 476 \\
6 & Central Asia & 5 & 1587 & 287 \\
7 & South and eastern Mediterranean & 5 & 4442 & 1547 \\
& Russia & 1 & 3030 & 365 \\
& Israel & 1 & 438 & 397 \\
& TOTAL & 36 & 17133 & 3948 \\
\hline
\end{tabular}

Notes. Country grouping: 1. Czech Republic, Estonia, Hungary, Latvia, Lithuania, Poland, Slovak Republic, Slovenia. 2. Bulgaria, Croatia, Romania 3. Albania, FYR Macedonia, Montenegro, Serbia, Turkey. 4. Bosnia and Herzegovina, Kosovo. 5. Armenia, Azerbaijan, Belarus, Georgia, Moldova, Ukraine. 6. Kazakhstan, Kyrgyz Republic, Mongolia, Tajikistan, Uzbekistan. 7. Egypt, Jordan, Lebanon, Morocco, Tunisia.

Table A.3. Means of the continuous variables (only firms reporting Management Quality data)

\begin{tabular}{lccc}
\hline & All countries & High Income & Low Income \\
\hline Managerial quality or MQS & 0 & 0.144 & -0.135 \\
SIZE & & & \\
Employees & 194.251 & 186.371 & 201.665 \\
$=$ log of & 4.418 & 4.436 & 4.402 \\
EDUCATION & & & \\
\% of graduates & 22.048 & 20.406 & 23.614 \\
$=$ log of & 2.730 & 2.590 & 2.864 \\
COMPETITION & & & \\
(\#) Number of competitors & 9.674 & 9.454 & 9.986 \\
(§) Number of competitors & 140.561 & 102.558 & 174.820 \\
AGE & 20.748 & 22.396 & 19.194 \\
MANAGER characteristics & & & \\
Years of experience & 20.594 & 20.895 & 20.310 \\
= log of & 2.814 & 2.830 & 2.798 \\
\hline
\end{tabular}

Notes. (\#) Excluded firms with too many competitors to count'.

(§) Attributing 300 competitors to firms with too many competitors to count. 
Table A.4. Distribution of the categorical variables (only firms reporting Management Quality data)

\begin{tabular}{|c|c|c|c|}
\hline & All countries & High Income & Low Income \\
\hline \multicolumn{4}{|l|}{ COMPETITION } \\
\hline competitors 0 & 103 & 51 & 52 \\
\hline competitors 1 to 5 & 777 & 443 & 334 \\
\hline competitors 6 to 10 & 388 & 246 & 142 \\
\hline competitors 11 to 50 & 260 & 159 & 101 \\
\hline competitors51 to 300 & 30 & 15 & 15 \\
\hline too many competitors to count & 1279 & 431 & 848 \\
\hline \multicolumn{4}{|l|}{ GVC PARTECIPATION } \\
\hline No partecipation in GVC & 2556 & 1129 & 1427 \\
\hline directGVC & 853 & 449 & 404 \\
\hline indirectGVC & 201 & 113 & 88 \\
\hline dirandindirGVC & 241 & 158 & 83 \\
\hline \multicolumn{4}{|l|}{ OWNERSHIP } \\
\hline domestic private & 3466 & 1677 & 1789 \\
\hline foreignprivate & 339 & 163 & 176 \\
\hline domesticpublic & 45 & 20 & 25 \\
\hline mixdomprivforpriv & 41 & 16 & 25 \\
\hline mixdomprivdompub & 2 & 1 & 1 \\
\hline \multicolumn{4}{|l|}{ TECHNOLOGY } \\
\hline mediumhighTech & 615 & 415 & 200 \\
\hline low tech & 2989 & 1459 & 1530 \\
\hline \multicolumn{4}{|l|}{ Manager's gender } \\
\hline Male & 3570 & 1690 & 1880 \\
\hline Female & 368 & 218 & 150 \\
\hline
\end{tabular}

Table A.5. Pearson's correlations of continuous variables

\begin{tabular}{|c|c|c|c|c|c|c|c|}
\hline & MQS & SIZE & EDUCATION & $\operatorname{Nr} \cdot \operatorname{comp}(\#)$ & $\operatorname{Nr} \cdot \operatorname{comp}(\S)$ & AGE & EXPERIENCE \\
\hline MQS & 1.000 & & & & & & \\
\hline SIZE & $0.187^{* * *}$ & 1.000 & & & & & \\
\hline EDUCATION & $0.077 * * *$ & $0.084 * *$ & 1.000 & & & & \\
\hline Nr. comp. (\#) & -0.033 & $-0.085^{* * *}$ & -0.009 & 1.000 & & & \\
\hline Nr. comp. (§) & -0.087 & $0.071 * * *$ & $-0.034 *$ & 1.000 & 1.000 & & \\
\hline AGE & $0.062 * * *$ & $0.224 * * *$ & 0.002 & $-0.051 * *$ & $-0.062 * * *$ & 1.000 & \\
\hline EXPERIENCE & $0.080 * * *$ & $0.042 * * *$ & $0.049 * * *$ & 0.026 & 0.002 & $0.192 * * *$ & 1.000 \\
\hline
\end{tabular}

Notes. All countries (Only firms reporting Management Quality data); $* *$ Significant at $1 \% ; * *$ Significant at $5 \%$; Significant at $10 \%$; (\#) Excluding firms with "too many competitors to count"; (§) Attributing 300 competitors to firms with "too many competitors to count".

Table A.6. Pearson's correlations of continuous variables

\begin{tabular}{|c|c|c|c|c|c|c|c|}
\hline & MQS & SIZE & EDUCATION & $\operatorname{Nr} \cdot \operatorname{comp}(\#)$ & $\operatorname{Nr} \cdot \operatorname{comp}(\S)$ & AGE & EXPERIENCE \\
\hline MQS & 1.000 & & & & & & \\
\hline SIZE & $0.208 * * *$ & 1.000 & & & & & \\
\hline EDUCATION & $0.186 * * *$ & $0.208^{* * *}$ & 1.000 & & & & \\
\hline Nr. comp. (\#) & -0.016 & -0.042 & -0.057 & 1.000 & & & \\
\hline Nr. comp. (§) & $-0.127 * * *$ & 0.004 & $-0.112 * * *$ & 1.000 & 1.000 & & \\
\hline AGE & $0.072 * * *$ & $0.271 * * *$ & $0.042 *$ & -0.040 & -0.025 & 1.000 & \\
\hline EXPERIENCE & 0.011 & 0.030 & $0.054 * *$ & 0.043 & 0.007 & $0.122 * * *$ & 1.000 \\
\hline
\end{tabular}

Notes. High Income countries (Only firms reporting Management Quality data); *** Significant at 1\%; ** Significant at 5\%; * Significant at $10 \%$; \#Excluding firms with "too many competitors to count"; §Attributing 300 competitors to firms with "too many competitors to count". 
Table A.7. Pearson's correlations of continuous variables

\begin{tabular}{llllllll}
\hline & MQS & SIZE & EDUCATION & Nr.comp $(\#)$ & Nr.comp $(\S)$ & AGE & EXPERIENCE \\
\hline MQS & 1.000 & & & & & \\
SIZE & $0.169^{* * *}$ & 1.000 & & & & \\
EDUCATION & $0.007^{* * *}$ & -0.036 & 1.000 & & & \\
Nr. comp. $(\#)$ & -0.043 & $-0.124^{* * *}$ & -0.034 & 1.000 & & & \\
Nr. comp. (§) & -0.09 & $0.108^{* * *}$ & -0.021 & 1.000 & 1.000 & & \\
AGE & 0.025 & 0.177 & -0.033 & -0.066 & $-0.059^{* *}$ & 1.000 & 1.000 \\
EXPERIENCE & $0.136^{* * *}$ & $0.052^{* * *}$ & 0.037 & 0.016 & 0.034 & $0.279^{* * *}$ & 1 \\
\hline
\end{tabular}

Notes. Low Income countries (Only firms reporting Management Quality data);

*** Significant at $1 \%$; * Significant at 5\%; * Significant at $10 \%$;

\#Excluding firms with "too many competitors to count"

$\S$ Attributing 300 competitors to firms with "too many competitors to count"

Table A.8. Mean MQSs by categorical variables (only firms reporting Management Quality data)

\begin{tabular}{|c|c|c|c|}
\hline & All countries & HIGH Income & LOW Income \\
\hline \multicolumn{4}{|l|}{ COMPETITION } \\
\hline competitors 0 & 0.0410 & 0.2417 & -0.1558 \\
\hline competitors 1 to 5 & 0.0641 & 0.2344 & -0.1617 \\
\hline competitors6to 10 & 0.1091 & 0.2229 & -0.0878 \\
\hline competitors 11 to 50 & 0.0531 & 0.2483 & -0.2542 \\
\hline competitors 51 to 300 & -0.1563 & 0.1153 & -0.4279 \\
\hline too many competitors to count & -0.1018 & -0.0258 & -0.1404 \\
\hline \multicolumn{4}{|l|}{ GVC PARTECIPATION } \\
\hline Not belonging to a GVC & -0.0775 & 0.0997 & -0.2176 \\
\hline directGVC & 0.2501 & 0.3238 & 0.1681 \\
\hline indirectGVC & -0.1646 & -0.0497 & -0.3122 \\
\hline dirandindirGVC & 0.1020 & 0.1340 & 0.0410 \\
\hline \multicolumn{4}{|l|}{ OWNERSHIP } \\
\hline domestic private & -0.0273 & 0.1102 & -0.1561 \\
\hline foreignprivate & 0.2441 & 0.4525 & 0.0510 \\
\hline domesticpublic & 0.2343 & 0.5359 & -0.0070 \\
\hline mixdomprivforpriv & 0.2838 & 0.2434 & 0.3096 \\
\hline mixdomprivdompub & 0.5461 & 0.5086 & 0.5835 \\
\hline \multicolumn{4}{|l|}{ TECHNOLOGY } \\
\hline mediumhighTech & 0.1721 & 0.3234 & -0.1416 \\
\hline low tech & -0.0421 & .0879 & 0.166 \\
\hline \multicolumn{4}{|l|}{ Manager's gender } \\
\hline Male & 0.0147 & 0.1603 & -0.116111 \\
\hline Female & -0.1423 & 0.0244 & -0.3845 \\
\hline
\end{tabular}

Appendix B. How to measure management score

BEEPS V-MENA ES includes a section on management practices in the areas of operations, monitoring, targets, and incentives. The operations question focuses on how the firm handles a process- related problem, such as machinery breaking down. The monitoring question covers the collection of information on production indicators. The questions on targets focus on the timescale for pro- duction targets, as well as their difficulty and employees' awareness of them. Lastly, the incentives questions cover criteria governing promotion, practices for addressing poor performance by employees, and the basis on which the achievement of production targets are rewarded. These questions were answered by all manufacturing firms with at least 20 employees (at least 50 employees in the case of Russia). In line with the method suggested and applied 
by Bloom et al. (2012) the scores for individual management practices (in other words, for individual questions) were converted into z-scores by normalizing each practice so that the mean was 0 and the standard deviation was 1 . To avoid putting emphasis on targets or incentives, unweighted averages were first calculated using the $\mathrm{z}$-scores of individual areas of the four management practices. An unweighted average was then taken across the z-scores for the four practices. Lastly, a z-score of the measure obtained was calculated. This means that the average management score across all firms in all economies in the sample is equal to zero. The management practices of individual firms deviate either left or right from zero, with those to the left denoting bad practices and those to the right indicating good practices.

$$
Z_{p_{i j c}}=\frac{P_{i j c}-\bar{P}_{i j c}}{\sigma_{P_{i j c}}}
$$

Where $Z_{p i j c}$ is the z-score of management practice $P_{i j c}$ of a firm $i$ in industry $j$ and country $c, P_{i}^{-} j c$ is the unweighted average of management practice $P_{i j c}$ across all observations in all countries and $\sigma_{P i} j c$ is the standard deviation of management practice $P_{i j c}$ across all observations in all countries.

The second step consist of the calculation of the average of z-scores of different practices belonging to the same area. This is necessary to avoid biases towards the area of the management represented by the higher number of questions in the survey. Thus, the following unweighted average is calculated:

$$
\bar{M}_{i j c}^{A}=\frac{1}{n_{P_{i j c} A}} \sum_{P_{i j c} \in A} Z_{p_{i j c}}
$$

Where $\bar{M}^{\mathrm{A}}{ }_{\mathrm{ijc}}$ is unweighted average of management practices (z-scores) $Z_{p i j c}$ the same management area $A$ (operations, monitoring, targets or incentives) of a firm $i$ in industry $j$ and country $c$.

The third step is to average the performance of a firm across different management areas:

$$
\tilde{M}_{i j c}=\frac{1}{4}\left(\bar{M}_{i j c}^{\text {Oper }}+\bar{M}_{i j c}^{\text {Monit }}+\bar{M}_{i j c}^{\text {Targ }}+\bar{M}_{i j c}^{\text {Incent }}\right)
$$

The final step of the calculations consists of the transforming the unweighted average in the z-score of the final measure with the mean zero and standard deviation 1:

$$
M Q_{i j c}=\frac{\tilde{M}_{i j c}-\overline{\tilde{M}}_{i j c}}{\sigma_{\tilde{M}_{i j c}}}
$$

The overall result $M_{i j c}$ can be used as a measure of the management quality (across countries and across practices) together with the deviations from the average score when the benchmark is a group of countries.

\section{Appendix C. Results from the interaction model}

In this Appendix we report and briefly comment the results of the estimated model with interactions.

The typical treatment of interactions in linear models is to consider the interaction as a product term of the main effects variables:

$$
Y_{i}=\beta_{0}+\beta_{1} X_{i 1}+\beta_{2} X_{i 2}+\beta_{3} X_{i 1} X_{i 2}
$$

rewritten as:

$$
Y_{i}=\beta_{0}+\beta_{1} X_{i 1}+\left(\beta_{2}+\beta_{3} X_{i 1}\right) X_{i 2}
$$

In this case, the effect of levels of $X_{i 2}$ on the outcome variable are intrinsically tied to specific levels of $X_{i 1}$ : the marginal contribution of $X_{i 2}$ is conditional on $X_{i 1}$ :

$$
\frac{\partial X_{i}}{\partial X_{i 2}}=\beta_{2}+\beta_{3} X_{i 1}
$$


Two scenarios occur. The first occurs when high levels of one variable have an accelerating effect on the other ( $\beta_{3}$ has the same sign as $\beta_{2}$ ), and the other when high levels of one variable have a dampening effect on the other $\left(\beta_{3}\right.$ has the opposite sign of $\left.\beta_{2}\right)$. So the sign of first-order interaction effects tells us quite a bit about the conditional effect that a given explanatory variable has on the outcome variable. The interpretation of a given coefficient's effect is now complicated by the requirement that it occurs at a specified level of the other explanatory variable. In our case all the covariates $X_{i}$ are interacted with the dummy variable, highGDP, which assumes value 1 if the firm is located in a country with high income and assumes value 0 if the firm is established in a country with low income. For instance, in the case of size, $S I Z E_{h G D P}$ is the interaction between the variable SIZE and the variable highGDP. The results of this model are consistent with those obtained by making two separated estimations in the two groups of countries: if the coefficient of a covariate is higher in the high (low) income group of countries, the sign of the corresponding interaction variable is positive (negative). Considering the cases when the coefficients of the interaction variables are significant, we can observe dampening and accelerating effects. From table C.1 we observe:

- The positive relationship between education and management quality is stronger in the high income countries;

- The advantage, in term of management quality, of the firms with a countable number of competitors is higher in the high-income countries than inlow-income.

- The positive relationship between technology and the management quality is stronger in the high income countries.

- $\quad$ The advantage, in term of management quality, of the firms participating in a GVC that make only direct exports with respect to firms not participating in a GVC is higher in low income countries.

- The advantage, in term of management quality, of the firm with mixed (domestic plus foreign private subjects; domestic private plus public subjects) ownership with respect to the firms with private domestic ownership is higher in low incomecountries.

At the end, we can identify an accelerating effect in high income countries for education competition and technology, whereas in low income the same accelerating effect is played by ownership (mixed) and participation in GVC. Results concerning technology, GVC and mixed (domestic plus foreign subjects) ownership are significant at 0.10 level; the other results are significant at the usual 0.05 level.

Table C.1. Firm and country characteristics and MQS (model with interactions)

\begin{tabular}{lc}
\hline & MQS \\
\hline SIZE & $0.152^{* * *}$ \\
SIZE_hGDP & $(4.95)$ \\
& -0.021 \\
EDUCATION & $(-0.50)$ \\
EDUCATION_hGDP & 0.004 \\
& $(0.12)$ \\
COMPETITION & $0.112^{* * *}$ \\
competitors_0 & $(2.69)$ \\
& \\
competitors_1to5 & -0.166 \\
competitors_6to10 & $(-1.01)$ \\
competitors_11to50 & -0.079 \\
& $(-1.00)$ \\
competitors_51to300 & 0.062 \\
& $(0.54)$ \\
\hline
\end{tabular}




\begin{tabular}{|c|c|}
\hline \multicolumn{2}{|l|}{ COMPETITION_hGDP } \\
\hline competitors_0_hGDP & $\begin{array}{c}0.429^{* * *} \\
(2.11)\end{array}$ \\
\hline competitors_1to5_hGDP & $\begin{array}{c}0.310^{* * *} \\
(2.97)\end{array}$ \\
\hline competitors_6to10_hGDP & $\begin{array}{l}0.207 \\
(1.50)\end{array}$ \\
\hline competitors_11to50_hGDP & $\begin{array}{c}0.416^{* *} \\
(3.05)\end{array}$ \\
\hline competitors_51to300_hGDP & $\begin{array}{l}0.446^{\circ} \\
(1.65)\end{array}$ \\
\hline \multicolumn{2}{|l|}{ GVC PARTICIPATION } \\
\hline directGVC & $\begin{array}{c}0.276^{* * *} \\
(3.33)\end{array}$ \\
\hline indirectGVC & $\begin{array}{l}-0.284 \\
(-1.59)\end{array}$ \\
\hline dirandindirGVC & $\begin{array}{c}0.0153 \\
(0.07)\end{array}$ \\
\hline \multicolumn{2}{|l|}{ GVC PARTICIPATION_hGDP } \\
\hline directGVC_hGDP & $\begin{array}{l}-0.213^{\circ} \\
(-1.92)\end{array}$ \\
\hline indirectGVC_hGDP & $\begin{array}{l}0.046 \\
(0.20)\end{array}$ \\
\hline dirandindirGVC_hGDP & $\begin{array}{l}0.061 \\
(0.25)\end{array}$ \\
\hline \multicolumn{2}{|l|}{ OWNERSHIP } \\
\hline foreignprivate & $\begin{array}{l}0.202^{\circ} \\
(1.94)\end{array}$ \\
\hline domesticpublic & $\begin{array}{l}0.107 \\
(0.53)\end{array}$ \\
\hline mix_domprivforpriv & $\begin{array}{l}0.710^{*} \\
(2.03)\end{array}$ \\
\hline mix_domprivdompub & $\begin{array}{c}1.160^{* * *} \\
(11.94)\end{array}$ \\
\hline \multicolumn{2}{|l|}{ OWNERSHIP_hGDP } \\
\hline foreignprivate_hGDP & $\begin{array}{l}0.036 \\
(0.24)\end{array}$ \\
\hline domesticpublic_hGDP & $\begin{array}{l}-0.036 \\
(-0.13)\end{array}$ \\
\hline mix_domprivforpriv_hGDP & $\begin{array}{l}-0.754^{\circ} \\
(-1.64)\end{array}$ \\
\hline Mix_domprivdompub_hGDP & $\begin{array}{c}-0.906 * * * \\
(-5.45)\end{array}$ \\
\hline \multicolumn{2}{|l|}{ TECHNOLOGY } \\
\hline mediumhighTech & $\begin{array}{l}-0.025 \\
(-0.29)\end{array}$ \\
\hline \multicolumn{2}{|l|}{ TECHNOLOGY_hGDP } \\
\hline mediumhighTech_hGDP & $0.179^{\circ}$ \\
\hline
\end{tabular}




\begin{tabular}{lc}
\hline & $(1.68)$ \\
AGE & -0.002 \\
& $(-0.94)$ \\
AGE_hGDP & 0.002 \\
& $(0.57)$ \\
Manager characteristics & YES \\
Manager characteristics_hGDP & YES \\
Constant & $-1.524 * * *$ \\
& $(-7.27)$ \\
\hline Obervations & 2325 \\
$\mathrm{R}^{2}$ & 0.1130 \\
$(*)$ Adj. $\mathrm{R}^{2}$ & 0.0987 \\
$\mathrm{~F}$ & $\mathrm{~F}(36,2287)=31.64$ \\
Prob $>\mathrm{F}$ & Prob $>\mathrm{F}=0.000$ \\
VIF & 5.37 \\
\hline
\end{tabular}

Notes. $t$ statistic in parentheses;

$(p<0.10),{ }^{*} p<0.05,{ }^{* *} p<0.01,{ }^{* * *} p<0.001$;

\section{Copyrights}

Copyright for this article is retained by the author(s), with first publication rights granted to the journal.

This is an open-access article distributed under the terms and conditions of the Creative Commons Attribution license (http://creativecommons.org/licenses/by/4.0/). 